
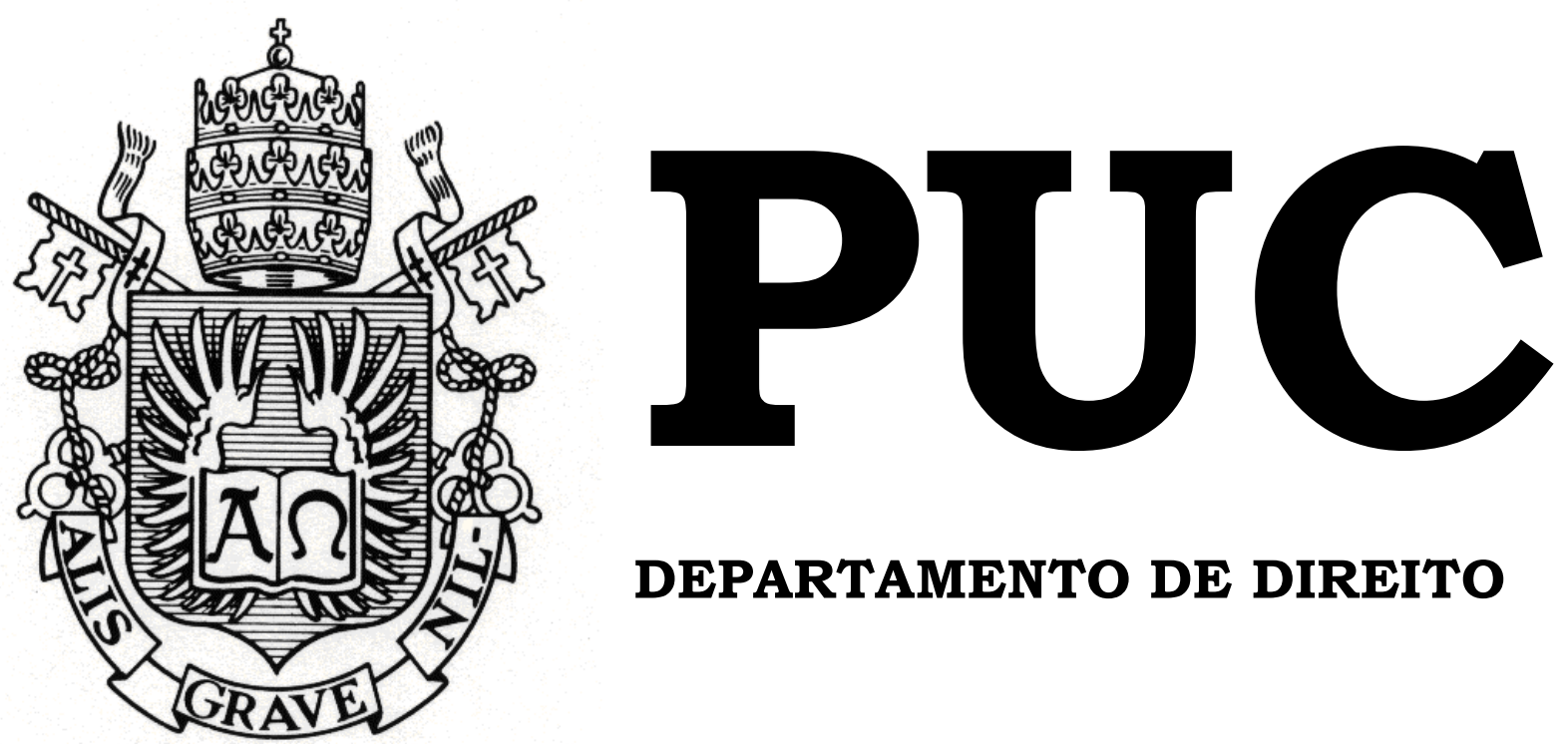

DEPARTAMENTO DE DIREITO

O PRINCÍPIO DA PUBLICIDADE NA ADMINISTRAÇÃO PÚBLICA E SEUS EFEITOS PRÁTICOS:

Alterações trazidas pela Lei 12.527/2011.

por

ANNA LUIZA AGHINA FERREIRA

ORIENTADORA: MARIANNA MONTEBELLO WILLEMAN

2012.2

PONTIFÍCIA UNIVERSIDADE CATÓLICA DO RIO DE JANEIRO

RUA MARQUÊS DE SÃO VICENTE, 225 - CEP 22453-900

RIO DE JANEIRO - BRASIL 


\title{
O PRINCÍPIO DA PUBLICIDADE NA ADMINISTRAÇÃO PÚBLICA E SEUS EFEITOS PRÁTICOS: Alterações trazidas pela Lei 12.527/2011.
} por

\section{ANNA LUIZA AGHINA FERREIRA}

\author{
Monografia apresentada \\ ao Departamento de \\ Direito da Pontificia \\ Universidade Católica do \\ Rio de Janeiro (PUC-Rio) \\ para a obtenção do Título \\ de Bacharel em Direito. \\ Orientadora: Marianna \\ Montebello Willeman
}


Dedico este trabalho, à minha mãe, por me ensinar a viver; ao meu pai, por me ensinar a sonhar; aо meu irmão pelo companheirismo e amor incondicionais; aos meus avós, por todo apoio e carinho; ao meu padrinho por me motivar e incentivar em todas as fases da vida. 


\section{AGRADECIMENTOS}

A entrega da monografia com o fim da faculdade é um importante marco de transição. É mais um ciclo que se fecha para dar espaço a novas experiências e desafios. Nesse momento, relembro todas as coisas boas que vivi nos últimos cinco anos e as pessoas maravilhosas que estiveram ao meu lado nesse período.

Em primeiro lugar, gostaria de agradecer aos meus pais Tita e Ivan, que sempre se dedicaram em proporcionar o melhor para mim, sem poupar esforços. Gratidão é uma palavra que não traduz o suficiente o que eu sinto por vocês. Todos os meus desejos que até hoje se concretizaram e as conquistas que atingi tiveram ao menos uma parcela de contribuição de vocês. Obrigada por me escutarem, pelos conselhos, pela paciência nas minhas crises, por apresentarem soluções e por me ajudarem a alcançar minhas vontades e lutar contra os meus medos. Sei que não é fácil ser pai e muito menos com uma filha como eu, cheia de dúvidas e ansiedades, tenho certeza que sem a ajuda de vocês eu não teria subido tantos degraus.

Agradeço também ao meu irmão Alfredo, que apesar de caçula às vezes tem a serenidade de um irmão mais velho e me ensina a conviver com as diferenças e ser uma pessoa mais amorosa e generosa, te amo mais que tudo.

Sou muito grata aos meus avôs Luiz e Anna Vera. Obrigada, Vô, por todos os conselhos inspiradores e pela sabedoria compartilhada. Sou muito orgulhosa de ser sua neta e feliz de ter seu reconhecimento. Obrigada, Vó, por se preocupar comigo e me incentivar a desbravar o mundo e curtir a vida. Sem sua ajuda e rezas, eu não teria tido tantas experiências incríveis. 
Gostaria de agradecer também ao meu padrinho Edu, que desde que sou pequena encontra formas diferentes de me motivar e impulsionar meu crescimento. Obrigada por toda a preocupação e carinho.

Agradeço pelo auxílio e atenção da minha orientadora Marianna Montebello Willeman, quem eu admiro muito desde o início da faculdade e considero uma profissional exemplar, professora atenciosa e fonte de inspiração.

Como já dizia o poeta: "Eu poderia suportar, embora não sem dor, que tivessem morrido todos os meus amores, mas enlouqueceria se morressem todos os meus amigos.". Não poderia deixar de agradecer aos meus amigos, essa família que eu escolhi e está ao meu lado tanto nas horas sérias como nas felizes. Obrigada por entenderem meu exílio social nos últimos meses e me confortarem nas horas de desespero, isso só me dá ainda mais certeza de que vocês estão guardados a sete chaves no meu coração e que os quero perto de mim em todos os momentos de celebração.

Em primeiro lugar, gostaria de agradecer ao Francisco Defanti e ao Filipe Seixo. Meus queridos Zé e Fil com quem tenho a sorte de conviver diariamente e são muito mais que colegas de trabalho, são meus professores e ombros amigos a que eu recorro sem pestanejar. Obrigada.

Agradeço também à Renata Kuschnir, Giuliana Pucarelli e Lívia Farias, que são meu orgulho e minha força. Obrigada, meninas, por todas as palavras tranqüilizadoras e os momentos de conforto. Sem vocês seria difícil continuar caminhando.

Agradeço a Beatriz Carnaval e Mayã Luíza Garcia por escutarem meus desabafos e postergarem nossas saídas, iremos compensá-las. Agradeço também ao Fábio Werneck que me ajudou a iniciar minha carreira jurídica, nunca vou esquecer. Agradeço ainda ao Renato Toledo e ao Francisco Garcia por tornarem meus dias mais felizes. 
Todos os meus amigos foram espetaculares e me trouxeram contribuições valiosas nesse período, gostaria de agradecer em especial a: Alexandru Olteanu, Aline Israel, André Tovar, Bernardo Doutel, Bruna Bueno, Gabriel Carneiro, Hans Page, Maria Vitória Campelo e Natalia Ayres.

Fico muito satisfeita por tudo que vivi até agora e espero que esta nova etapa traga ainda mais coisas e pessoas especiais pelas quais eu possa agradecer. 
RESUMO: A recente edição da Lei de Acesso à Informação e os movimentos internacionais a favor da transparência são os motivos principais que deram ensejo a elaboração do presente trabalho. O estudo aborda o princípio da publicidade na administração pública e sua aplicação prática, para tanto analisa sua importância e objetivos, bem como os dispositivos constitucionais e infraconstitucionais que o tutelam e o limitam, sem deixar de desenhar sua trajetória para uma noção de transparência. Posteriormente, aponta as principais inovações trazidas pela Lei $12.527 / 2011$ e suas repercussões para a efetivação do princípio da publicidade e o direito de acesso à informação.

PAlAVRAS CHAVES: Direito Administrativo - Administração Pública Princípio da Publicidade - Direito de Acesso a Informações - Lei de Acesso à Informação - Transparência - Exceções à Publicidade 


\section{SUMÁRIO}

I. INTRODUÇÃ

1.1. Definição do Princípio da Publicidade..........................................................12

1.2. Objetivos do Princípio da Publicidade.........................................................15

1.3.Superação da ideia clássica de publicidade para uma noção de transparência.21

\section{O PRINCÍPIO DA PUBLICIDADE NO ORDENAMENTO JURÍDICO BRASILEIRO}

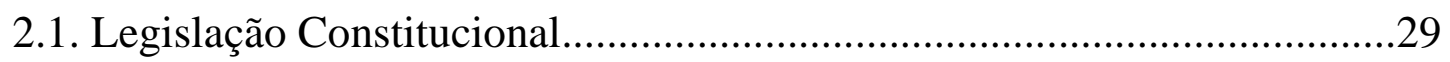

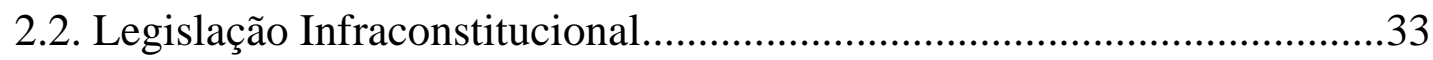

III. DIREITO À INFORMAÇÃO: Alterações trazidas pela Lei $12.527 / 2011$

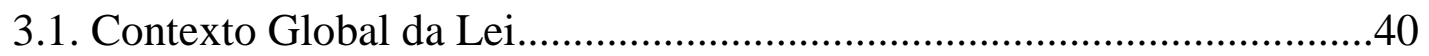

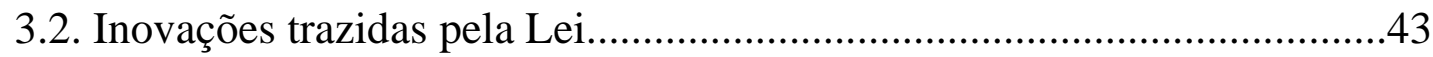

3.2.1. Panorama Geral e Noções Principais da Lei............................................43

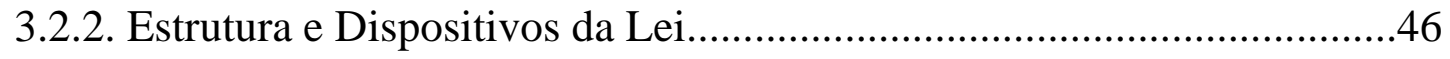

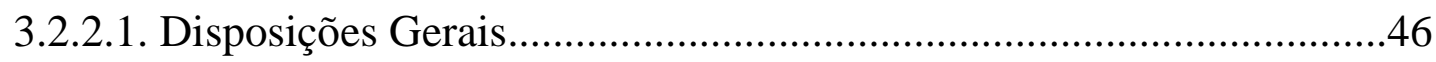

3.2.1.2. Garantias do Direito ao Acesso............................................................4

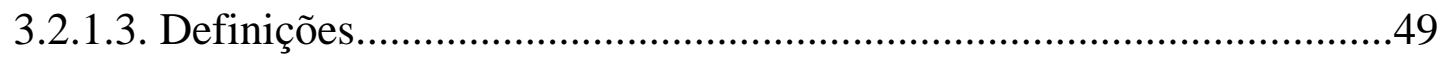

3.2.1.4. Divulgação proativa de informações.....................................................50

3.2.1.5. Processamento dos pedidos de informação...........................................52

3.2.1.6. Recursos e Comissão Mista de Reavaliação de Informações...............54

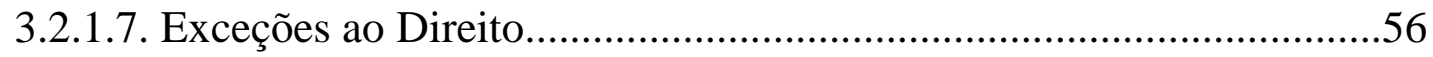

3.2.1.8. Tratamento de Informações Pessoais.....................................................60 


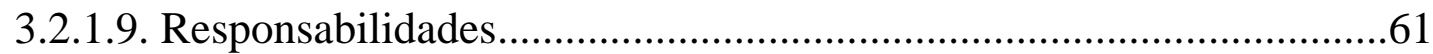

3.2.1.10. Alterações na Lei n. 8.112/1990.......................................................63

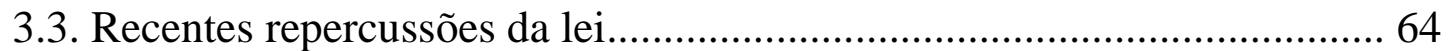

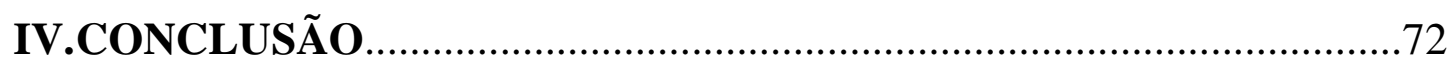

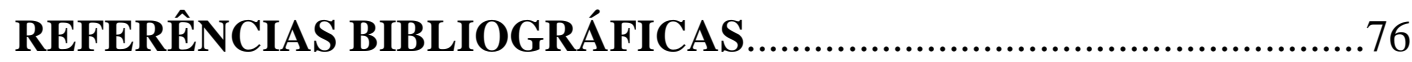




\section{LISTA DE ABREVIAÇÕES}

CGU - Controladoria Geral da União

CONARQ - Conselho Nacional de Arquivos

CRFB - Constituição da República Federativa do Brasil

LAI - Lei de Acesso à Informação

MS - Mandado de Segurança

Simpa - Sindicato dos Municipários de Porto Alegre

SINAR - Sistema Nacional de Arquivos

SISNAMA - Sistema Nacional do Meio Ambiente

SL - Suspensão de Liminar

SS - Suspensão de Segurança

STF - Supremo Tribunal Federal

TRF2 - Tribunal Regional Federal da $2^{\mathrm{a}}$ Região

TSE - Tribunal Superior Eleitoral 
"Todas as ações relativas ao direito de outros homens, cuja máxima não é suscetível de se tornar pública, são injustas."

(Kant) 


\section{INTRODUÇÃO}

A administração pública é responsável pela gestão dos interesses gerais da sociedade. Em sua atuação, o Estado, de forma direta ou indireta, busca a satisfação das necessidades coletivas, sempre com fulcro no interesse público. Para que se evite a ocorrência de arbitrariedades e abusos na prática de atos administrativos, a persecução do interesse público deve ser orientada por uma série de princípios que balizam a atuação do poder público.

Tais princípios estão previstos na Constituição da República, mormente no caput do art. 37, e na legislação infraconstitucional (p. ex., Lei $\mathrm{n}^{\circ}$ 9.784/1999). Não obstante serem todos de extrema relevância para a correta compreensão da atividade administrativa, as razões pelas quais o tema deste estudo recai apenas sobre o princípio da publicidade se dá por duas ordens.

A primeira é a recente edição da Lei n. 12.527/2011, que disciplina o acesso à informação e traz novos e importantes mecanismos que possibilitam ao cidadão a obtenção de dados que sejam de seu interesse particular ou até de interesse geral da sociedade.

A segunda é a expansão internacional do conceito de transparência. Com efeito, o Brasil tem sido um dos países pioneiros na implementação de políticas de transparência, importante marco para um país que há poucas décadas ultrapassou um regime ditatorial, no qual vigorava a cultura do sigilo.

O objetivo central do presente trabalho é apresentar, de forma objetiva e empírica, a importância do princípio da publicidade, sua evolução para um novo conceito de transparência, e a repercussão desta na esfera mundial, bem como apresentar as principais alterações trazidas pela Lei n. 12.527/2011 e a forma como tais mudanças estão sendo aplicadas na prática. 


\subsection{Definição do Princípio da Publicidade}

Para que sejam analisadas as aplicações e os efeitos práticos do princípio da publicidade é necessário clarificar sua abrangência e o seu telos. Assim, é oportuno, neste primeiro momento, estender-se na compreensão do termo "publicidade".

De acordo com o dicionário Aurélio, publicidade pode ser definida como:

"1.Qualidade do que é público ou do que é feito em público. 2. Publicação de matéria jornalística de interesse de uma organização, empresa, indivíduo, etc. 3. Propaganda."

A identificação dos vários significados do termo se faz importante para que seja exposta uma ressalva inicial. O vocábulo em questão é mais comumente utilizado no sentido de propaganda. Embora tal referência seja também empregada no ordenamento pátrio, em especial no Código de Defesa do Consumidor, salienta-se que esta abordagem não será objeto no presente estudo.

A análise do conceito será feita aqui sob o prisma da administração pública. Nesse sentido, faz-se mister colacionar algumas definições do princípio. Nas palavras de José Maria Pinheiro Madeira: "Publicidade é a divulgação oficial do ato para conhecimento público e início de seus efeitos externos." 2 Lucas Rocha Furtado, por sua vez, define: "O princípio da publicidade pode ser traduzido como o dever da Administração de dar transparência aos seus atos. "’3. Ainda, para José Afonso da Silva:

\footnotetext{
FERREIRA, Aurélio Buarque de Holanda. Mini Aurélio Século XXI: o minidicionário da língua portuguesa. $4^{\text {a }}$ Ed. Rio de Janeiro: Nova Fronteira, 2002. p. 566 - 567

2 MADEIRA, José Maria Pinheiro. Administração Pública. 10ª Ed. Rio de janeiro: Elsevier, 2008. p.25.

3 FURTADO, Lucas Rocha. Curso de Direito Administrativo. Belo Horizonte: Fórum, 2007. p.108.
} 
"A Publicidade sempre foi tida como um princípio administrativo porque se entende que o Poder Público, por ser público, deve agir com a maior transparência possível, a fim de que os administrados tenham, a toda hora, conhecimento do que os administradores estão fazendo. ",

Assim, a publicidade aqui tratada é igualmente um veículo de informação. No entanto, mais do que a simples divulgação, ela se traduz em um dever estatal. É por orientação de tal princípio que o os órgãos públicos dão publicidade e notoriedade aos seus atos, procedimentos, decisões e atividades.

Os conceitos expostos podem ser facilmente compreendidos quando se analisa a qualidade eminentemente prática de tal princípio, isto porque ele é um instrumento poderoso e necessário para a consolidação do conceito de Estado Democrático de Direito.

Como bem se sabe, o Estado Democrático de Direito fundamenta-se no princípio da soberania popular. Esta, por sua vez, consagra a ideia de participação do povo na coisa pública. A democracia baseia-se na capacidade dos indivíduos de ingressarem no processo de tomada de decisões estatais. Desta forma, tendo em vista que a base democrática reside na premissa de que o povo é a fonte do poder, a participação popular deve ocorrer das mais variadas maneiras.

Ainda que o exemplo mais óbvio e de repercussão mais visível de participação sejam as eleições dos agentes políticos, a atuação dos cidadãos não se limita a este ponto. Muito pelo contrário, este é o passo inicial. As sociedades democráticas possuem diferentes mecanismos participativos que variam desde a formação das instituições representativas até a necessidade de realização de consultas e audiências públicas para a tomada de decisões relevantes (previstas na Lei n. 9.784/99 que regula o Processo Administrativo Federal).

4 SILVA, José Afonso da. Curso de Direito Constitucional Positivo. 30 ${ }^{\text {a }}$ Ed. São Paulo: Malheiros. p. 669. 
Diante da análise deste modelo de governo, é possível perceber a importância do princípio em questão. Uma vez que o poder emana do povo e seu exercício reverte-se em proveito deste, por meio de representantes eleitos, a troca de informações se faz necessária e constante. Por óbvio, o cidadão tem o direito de obter dos seus representantes todas as informações referentes à administração da coisa pública. Uma vez eleitos, não há um rompimento entre os agentes políticos e a sociedade. Muito pelo contrário: há necessidade de manutenção de um constante elo de debates democráticos.

Por conseguinte, para que ocorra a participação popular efetiva nas atividades estatais, é preciso que os indivíduos tenham conhecimento dos atos praticados pelo Estado. Por um lado os indivíduos devem pleitear suas demandas, expor suas reivindicações aos governantes que, por sua vez, devem ouvi-los, atender seus interesses e dar execução às medidas necessárias para melhoria das condições sociais, econômicas e culturais. Ao mesmo tempo, os cidadãos têm direito de conhecer a atuação de governantes e verificar a implementação dos projetos apresentados.

Pode-se afirmar, portanto, que, ao contrário dos regimes totalitários em que o segredo de Estado e o controle da informação perpetuam-se, a democracia é o regime do poder visível em que os atos, despachos, programas e ações do Poder Público são conhecidos pelos cidadãos ${ }^{5}$. A regra é a publicidade e ampla divulgação dos atos da Administração, sendo o sigilo permitido apenas em hipóteses excepcionais, previstas em lei.

Desta forma, a publicidade torna-se fundamental para permitir tanto a defesa dos interesses individuais quanto a promoção dos interesses públicos. Nesta medida, ocorre um incentivo à acessibilidade da coisa pública a todos os grupos sociais.

5 BINENBOJM, Gustavo. O princípio da publicidade administrativa e a eficácia da divulgação de atos do poder público pela internet. Salvador: Revista Eletrônica de Direito do Estado, 2009. Disponível em: <https://www2.mp.pa.gov.br/sistemas/gcsubsites/upload/39/princdapublicidade.pdf $>$ Acesso em: 26 de setembro de 2012. 
Assim, o princípio da publicidade consagra o direito constitucional dos indivíduos à obtenção de informações relativas às atividades dos agentes públicos. Estas, a seu turno, devem ser realizadas sempre no interesse da coletividade e buscando o cumprimento das determinações legais previamente fixadas ${ }^{6}$.

\subsection{Objetivos do princípio da publicidade}

Diante de tais considerações iniciais, é possível apresentar dois objetivos fundamentais inerentes ao princípio da publicidade: (i) permitir o acesso à informação; e (ii) propiciar o controle da atuação estatal. Vejamos de forma mais aprofundada.

Em primeiro lugar, a publicidade é um meio de divulgar a informação. É a partir da publicização que a Administração permite a veiculação de seus atos, contratos e outros instrumentos jurídicos, levando-os ao conhecimento público. Ela garante o dever constitucional do cidadão de ter acesso à informação acerca das ações e omissões praticadas pelos agentes estatais e até mesmo dos particulares quando estes estiverem atuando em nome e com os recursos do Poder Público. ${ }^{7}$

A publicidade, no entanto, não se confunde com a publicação. Com efeito, esta é apenas uma das muitas formas que a Administração possui de dar publicidade aos seus atos, podendo ser feita por vários meios de comunicação como diários oficiais, meios eletrônicos, notificação direta, afixação de avisos, etc.

Caso a lei estabeleça uma forma de divulgação, esta deve ser observada. Desta maneira, é importante ressaltar que somente a veiculação da notícia pela

\footnotetext{
6 MOREIRA, Egon Bockmann. Processo Administrativo: Princípios Constitucionais e a Lei

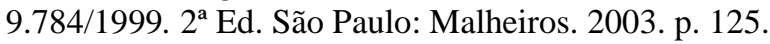

7 JUSTEN FILHO, Marçal. Curso de direito administrativo. $8^{\text {a }}$ Ed. Belo Horizonte: Fórum, 2012. p. 309.
} 
imprensa escrita (não oficial), falada ou televisada, o princípio não será dado como satisfeito, isto porque é necessário que se atinja a essência deste ${ }^{8}$, qual seja a ampla divulgação ou a comunicação do interessado de acordo com os meios previstos em lei. Neste sentido:

"O particular não experimenta os efeitos do ato administrativo a partir do momento em que este deixa o recinto de trabalho da autoridade administrativa, mas quando ele, cidadão, é formalmente notificado da decisão (através da publicação no Diário Oficial, carta com Aviso de Recebimento ou intimação pessoal - a depender do caso concreto (...)","

Neste contexto, a divulgação oficial do ato, portanto, possui um duplo papel: não apenas torna pública a informação - permitindo o acesso à população ao conteúdo do material estatal contido no instrumento veiculador como também marca o início da produção dos efeitos externos do ato divulgado. "Até a sua publicidade o ato é documento próprio da autoridade competente, 10 .

Ao ser publicizado, o ato passa a repercutir nas diversas esferas jurídicas como, por exemplo, dando início à contagem de prazos. Desta forma, para que os atos e contratos possam produzir efeitos (requisito de eficácia) perante as partes e terceiros - e consequências jurídicas fora dos órgãos que os emitem é necessária a sua publicização ${ }^{11}$.

Como dito, a publicidade do ato administrativo é um requisito de eficácia dos atos administrativos. Isso significa que a simples publicação não tem o condão de convalidar atos que porventura sejam irregulares. De forma similar, os atos regulares não poderão dispensar a publicação se a lei assim o exigir $^{12}$. Assim, não se trata de um requisito de formação do ato: este já está

\footnotetext{
MADEIRA, José Maria Pinheiro. Op. Cit. p. 29. MOREIRA, Egon Bockmann. Op. Cit. p. 139. Ibid. p.138.

MADEIRA, José Maria Pinheiro. Op. Cit. p. 26. Ibid. p. 26.
} 
formado e é perfeito e válido, mas, para que produza seus regulares efeitos, é indispensável que ocorra a sua publicização.

$\mathrm{O}$ rol de obrigados ao dever de prestar informações é amplo. O inciso XXXIII, do artigo $5^{\circ}$ da Constituição da República atribui tal encargo aos "órgãos públicos". Nesse sentido, não apenas a Administração Pública direta e indireta está incumbida de tal obrigação, mas também "toda e qualquer pessoa jurídica ou instituição cujo objeto seja a prestação de função pública ou que titularize, ainda que temporariamente e em regime precário, recursos ou bens públicos." "13. O caput do art. 37 da CRFB/1988, por sua vez, estabelece que, ao lado dos princípios da legalidade, impessoalidade, moralidade, e eficiência, o princípio da publicidade é de observância obrigatória da "administração pública direta e indireta de qualquer dos Poderes da União, dos Estados, do Distrito Federal e dos Municípios”.

A divulgação de informações, portanto, deve ser feita de modo impessoal e generalizado. Em princípio ela leva a conhecimento público informações de interesse coletivo e geral, qual seja:

"O interesse coletivo é titularizado por grupo de pessoas ligadas entre si por uma relação jurídica própria que as unifica. (...) São interesses transindividuais, pertencentes a uma coletividade específica, e não especiais às pessoas que fazem parte dessa coletividade." 14 .

O interesse geral, por sua vez:

“(...) diz respeito ao todo do corpo social. Poder-se-ia equipará-lo ao interesse público em sentido amplo. (...) Ao contrário dos interesses coletivos, que se dirigem a um número determinado (ou ao menos imediatamente determinável) de pessoas, o interesse geral é mais abstrato e diz respeito a um grupo difuso e indeterminado."

3 MOREIRA, Egon Bockmann. Op. Cit. p. 129-130.

14 Ibid. p. 127.

15 Ibid. p. 128. 
Pode ocorrer, no entanto, que os dados veiculados digam respeito a um interesse particular, hipótese em que a questão envolva o interesse de um ou mais sujeitos específicos e determinados. "[T]rata-se de informações vantajosas e úteis ao interessado que as requer (moral, social ou materialmente importantes) ${ }^{\prime \prime 16}$. Neste caso, a publicidade irá se configurar como um direito subjetivo e individual ${ }^{17}$, podendo a lei prever uma forma especifica para a comunicação dos individualmente afetados.

Como visto, a informação deve ser conhecida pelos interessados direta ou indiretamente. Todavia, é possível que, em certas situações, determinadas especificamente pela lei, haja restrições a divulgação das informações.

O artigo $5^{\circ}$, inciso XXXIII, da Constituição da República, estabelece que o direito de receber informações é ressalvado nos casos "cujo sigilo seja imprescindível à segurança da sociedade e do Estado”. O mesmo dispositivo legal em seu inciso LX prevê ainda que "a lei só poderá restringir a publicidade dos atos processuais quando a defesa da intimidade ou o interesse social o exigirem".

Conclui-se que apenas em razão da segurança nacional, do direito à intimidade ou do interesse público a publicidade dos atos e atividades da administração pode ser restringida. Nestes casos deve haver um juízo de ponderação para avaliar qual dos princípios em colisão deverá sofrer menos restrição.

Se estivermos diante de uma situação em que a publicidade do ato aniquilará o interesse público, este deverá preponderar. Do mesmo modo, não é permitido que se divulgue informação que irá violar a esfera de intimidade do indivíduo de forma injustificada. Segundo José Maria Pinheiro Madeira:

Ibid. p. 127.

7 JUSTEN FILHO, Marçal. Op. Cit. p.310. 
“(...)[S]e por um lado, a Administração Pública tem o dever de informar e de ser transparente quanto a seus atos administrativos, a fim de serem resguardados interesses públicos, e por via reflexa, particulares, por outro, este dever pode ser restringido sob a forma de sigilo, a fim de serem garantidos interesses particulares $e$, por via reflexa, o próprio interesse público. ${ }^{\text {,ls }}$.

Verifica-se, no entanto, que a qualificação da informação como sendo sigilosa não é discricionária. Ato contínuo, o agente público só poderá resguardar sigilo sobre um determinado dado ou fato quando estiver diante de uma das ressalvas legais, devendo expressamente motivar.

Assim, não se trata de uma questão de escolha aleatória do administrador que fornece ou não a informação quando desejar. Via de regra, ele deverá divulgá-la e da mesma forma terá o dever de guardá-la - não lhe sendo, portanto, uma faculdade - quando configurar uma violação à intimidade, segurança nacional ou interesse público. ${ }^{19}$. Em decorrência disto, se o administrador optar por manter em segredo quaisquer outras informações que não se enquadrem nas situações previstas pela lei, o ato será nulo.

O segundo objetivo da publicidade é a viabilização do controle dos atos públicos. Essa finalidade do princípio é de extrema relevância, pois permite a verificação da existência de eventuais vícios e irregularidades na atuação da Administração feita tanto pelos controles estatais - efetuados pela própria Administração e pelos demais Poderes - como pelos sociais - feito pelos cidadãos e entidades da sociedade civil.

O controle a que se refere pode ser acerca da forma, ou, então, do conteúdo do ato administrativo. Sua importância versa sobre a possibilidade de se verificar se a atividade administrativa estava circunscrita dentro dos limites legais. Sendo assim, se o ato não observou a forma de publicização determinada pela lei (p. ex., prescindiu uma assinatura ou, então, extrapolou a

\footnotetext{
8 MADEIRA, José Maria Pinheiro. Op. Cit. p.27.
}

19 MOREIRA, Egon Bockmann. Op. Cit. p. 131. 
matéria de competência do órgão), tal conferência poderá ser realizada e será possível requerer as devidas correções e a aplicação de eventuais sanções.

Sendo a coisa pública, ela não pode ficar às escondidas, devendo a atividade do Estado ser conhecida pelo cidadão. Isso permite uma maior eficiência de atividade administrativa, pois aumenta-se o número de fiscais da administração sem ônus para os contribuintes. Consequentemente, o fato de a decisão vir ao conhecimento público gera uma alteração na própria Administração. Uma vez que esta possui a consciência que seus atos estarão sujeitos ao olhar crítico de seus administrados, busca-se uma atuação de forma mais proba, visando atender aos objetivos traçados e evitando irregularidades e corrupções.

O controle exercido pelos administrados é, como já mencionado, pura consequência do Estado Democrático de Direito. Os cidadãos possuem o direito de acompanhar as atividades do Poder Público na medida em que buscam tanto o atendimento às suas necessidades básicas como o cumprimento dos demais princípios da administração pública, especialmente aqueles previstos no artigo 37, caput, da Constituição da Republica: legalidade, impessoalidade, moralidade, publicidade e eficiência.

Desta forma, verifica-se a importância do princípio tanto para a própria Administração quando para os administrados. A publicização do ato permite o acesso à informação pelos cidadãos e dá início aos seus efeitos. Ademais, torna possível o controle dos atos e atividades administrativas pelos demais Poderes, e pela própria Administração e pelos indivíduos, colaborando para uma atuação mais virtuosa do Poder Executivo e minimizando eventuais máculas. 


\subsection{Superação da ideia clássica de publicidade para uma noção de transparência}

Fixados os objetivos visados pelo princípio da publicidade, pode-se indagar se sua aplicação prática é efetivamente capaz de alcançá-los. Tal consideração se faz necessária, pois, embora seja possível o acesso aos dados, atividades e atos da administração, pode ocorrer que sejam impostas barreiras na absorção de seu conteúdo. Isto se dá porque muitas vezes os atos apresentam um excesso de termos técnicos e uma linguagem demasiadamente rebuscada que dificultam sua assimilação e utilização pelo cidadão.

Tais obstáculos estão diretamente relacionados à evolução histórica do princípio e da própria Administração Pública. Apenas a título de contexto, atenta-se para o fato de que, a Administração Pública, já em suas origens, se posicionava em um patamar superior ao administrado.

No intuito de reforçar o Poder Executivo aproveitou-se da separação e independência dos Poderes do Estado, para criar um procedimento próprio - o Contencioso Administrativo - e um direito próprio - o Direito Administrativo. Este isolamento, tanto em relação aos demais poderes quanto aos indivíduos permitiu que sua autonomia fosse reforçada e protegida.

Como resultado, a Administração se mostrou relutante em permitir uma maior interação entre o Estado e a sociedade, acarretando no seu retardo na absorção das influências liberais. Ao revés, buscou enfatizar os institutos que consagravam o poder de império e os princípios de autoridade, como por exemplo, sua atuação discricionária, a exclusão do administrado no processo decisório, a executoriedade e a autotutela ${ }^{20}$.

Tais características repercutiram no próprio procedimento utilizado pela Administração. $\mathrm{O}$ ato administrativo aparecia como uma manifestação de

\footnotetext{
${ }^{20}$ MOREIRA NETO, Diogo de Figueiredo. Mutações do Direito Administrativo. Rio de Janeiro:
} Renovar, 2000. p. 9-10. 
vontade (soberana, autoritária e unilateral) da Administração e meio de exercício do poder administrativo. Influenciada pelo Direito Privatista, a Administração negligenciou o processo de formação da vontade do ato administrativo, voltando o seu foco na consolidação da decisão, traduzida aqui como o ato administrativo. Assim, a atividade administrativa permanecia livre em sua trajetória e regrada em seu resultado ${ }^{21}$.

Neste período inicial, na vigência do Estado liberal, o ato administrativo apresentava-se como o momento de exteriorização da vontade da Administração que, revestida de autoritarismo, propiciava pouca interação com os cidadãos.

A evolução para o Estado liberal e a adoção de novas funções fizeram com que a Administração ultrapasse as relações de Poder com os indivíduos e se expandisse para relações de colaboração e participação. $\mathrm{O}$ ato administrativo adquiria assim um caráter de instrumento de satisfação de interesses individuais. Ele perdeu sua posição de única expressão da atividade administrativa que passou a se materializar em outras exteriorizações jurídicas $^{22}$.

Nas últimas duas décadas do século XX, com o Estado neoliberal, as atividades da administração expandiram-se ainda mais para áreas de direção e planificação e com capacidade para atingir um número muito maior de sujeitos. Isto fez com que surgissem "fortes demandas por participação, apontando para a necessidade de revalorização do cidadão como sujeito de direito administrativo, ${ }^{, 23}$.

Essa mudança de paradigma das relações entre a Administração e os administrados reforçou sua posição como sujeitos titulares de direitos e diminuiu a veia autoritária do poder público. Aquela posição inicial de

\footnotetext{
${ }^{21}$ BAPTISTA, Patrícia. Transformações do direito administrativo. Rio de Janeiro: Renovar, 2003. p. $228-230$.

${ }^{22}$ Ibid. p. $230-233$.

${ }^{23}$ Ibid. p. 233.
} 
elevação da Administração foi modificada para embasar novas relações pautadas na igualdade com o cidadão. Resultado disto pôde ser verificado na ênfase do processo administrativo em detrimento ao ato ${ }^{24}$.

Neste bojo, o processo administrativo adquiriu um novo espaço e molde. Alterou aquele modelo inicial que se traduzia em uma sequência de pequenos atos que expressavam a preparação para a decisão final. Passou a se apresentar como fenômeno dinâmico, capaz de institucionalizar a participação administrativa e emanar interesse e informações do poder público. Um instrumento necessário para garantia e concretização dos direitos fundamentais em especial os direitos de participação ${ }^{25}$.

Tal trajetória histórica se mostra importante para compreendermos o seguinte: a Administração Pública possui em suas raízes características de uma cultura do sigilo e manutenção do poder de império. Embora tenham ocorrido importantes mudanças - como, por exemplo, o aperfeiçoamento do conteúdo das decisões, a aproximação dos cidadãos com o Estado, a justiça administrativa propiciada pela valorização do processo administrativo - não podemos ignorar que alguns aspectos da conduta administrativa ainda conservam traços desse seu passado autoritário.

A Era das Comunicações propiciou uma maior propagação da informação por novos meios e fontes e elevou os índices de educação da sociedade colaborando para uma conscientização de seus interesses e seu poder na ingerência estatal. Tal cadeia de acontecimentos contribuiu para a formação de uma sociedade mais participativa no que tange às atividades desenvolvidas pelo Estado ${ }^{26}$.

Essa consciência da sociedade mobilizou os indivíduos a abandonarem esse distanciamento e conformismo buscando novos métodos participativos além da representação política - notadamente insuficiente e repleta de vícios

\footnotetext{
${ }^{24}$ Ibid. p. $234-237$.

${ }^{25}$ Ibid. p. $237-240$.
} 
antropológicos, sociológicos e eleitorais - baseados na autonomia coletiva, direito de participação coletivo e na defesa de interesses específicos ${ }^{27}$.

Assim, ocorreu uma pluralização das instituições participativas que não só englobou os mecanismos já tradicionais como o plebiscito, referendo e iniciativa popular, mas ampliou-se para novas formas como a coleta de opinião, o debate público, a audiência pública, as agências reguladoras e a delegação atípica à entidades intermediárias (pessoas de direito público ou privado incumbidas à prestação de serviços públicos que possibilitam a reaproximação entre a sociedade e Estado como parceiros ${ }^{28}$.

Deste modo, o progresso eletrônico reduziu os custos de intercâmbio entre os indivíduos e instituições e aumentou a velocidade de trocas de dados, imagens e pesquisas garantindo, assim, maior legitimidade e eficiência às decisões estatais.

Soma-se a esse fator, a afirmação do constitucionalismo e sua evolução de uma concepção de legalidade para a legitimidade. O conceito ultrapassou a idéia inicial restrita à declaração de liberdades, direitos e garantias e organização dos poderes estatais e estabelecimento de metas programáticas que instituía um Estado de Direito. Mais que isto, passou-se a valorizar processos legitimatórios e a cidadania em todas as suas manifestações e aspectos, buscando a licitude do interesse público como valor constitucional e instituindo um Estado Democrático ${ }^{29}$.

Essas mudanças ocorridas na sociedade impulsionaram a demanda por transformações do Estado e uma alteração na postura imperial do interesse público, para se tornar um instrumento da sociedade. Ademais, a administração, encarada como um serviço prestado ao público, passou a necessitar da colaboração e cooperação dos cidadãos para adquirir mais

\footnotetext{
${ }^{26}$ MOREIRA NETO, Diogo de Figueiredo. Op. Cit. p.12 - 13.

${ }^{27}$ Ibid. p.13.

${ }^{28}$ Ibid. p. 14 .

${ }^{29}$ Ibid. p.15- 16.
} 
eficiência, modicidade e legitimidade. Neste contexto, vislumbra-se a inversão do poder hierárquico sobre seus liderados e a consagração do primado do indivíduo sobre o Estado $^{30}$.

Entendido esse panorama de transformações é possível perceber a importância do princípio da publicidade para esse novo modelo de governo. Todos os mecanismos participativos mencionados esvaziam-se caso as finalidades do princípio não sejam efetivamente alcançadas. No mesmo passo, a adoção dessa postura mais crítica, tanto dos indivíduos quanto dos poderes externos, em relação à atuação da Administração, permitiu que fossem formulados novos questionamentos em relação ao princípio.

Ocorre que, a simples noção de publicidade está ficando ultrapassada diante de um novo conceito de transparência. Atualmente, vêm-se formando um entendimento entre os doutrinadores de todo o mundo que a simples publicização da informação não é suficiente para atingir sua acessibilidade e controle. Para que ela possa atender efetivamente seus objetivos, é necessária que ela seja veiculada de forma clara, linguagem simples e acessível, evitandose termos técnicos, somente assim é que ela poderá ser apreendida e utilizada pelos seus destinatários.

Nas palavras de José Maria Pinheiro Madeira:

“(...) [P]or estarem intimamente ligadas, a publicidade está evoluindo para a transparência, embora exista uma sutil diferença entre esses termos: enquanto a publicidade se traduz no simples ato de publicar, a transparência é mais do que isto, pois que, além de publicar, o texto tem que ser claro, de fácil entendimento, sem conter expressões cheias de malabarismos verbais, de difícil interpretação, que certamente ferem a transparência do ato. ",31

É nesse âmbito que se evita a exacerbação de formalidades, e procura-se dar maior abertura, fluidez e maleabilidade à divulgação da informação, como

\footnotetext{
${ }^{30}$ Ibid. p.14-16.

${ }^{31}$ MADEIRA, José Maria Pinheiro. Op. Cit. p30.
} 
forma de permitir a instrumentalização dos princípios de participação e impessoalidade com a efetivação dos controles da Administração Pública no âmbito estatal e social ${ }^{32}$.

No que tange às mudanças na forma de encarar o princípio também é possível mencionar outro conceito importante, diretamente relacionado à questão de transparência, que é o conceito de accountability. Traz-se a tona sua definição de acordo com Guillermo O’Donnell:

"[é]a existência de agências estatais que têm o direito e o poder legal e que estão de fato dispostas e capacitadas para realizar ações, que vão desde a supervisão de rotina a sanções legais ou até o impeachment contra ações ou emissões de outros agentes ou agências do Estado que possam ser qualificadas como delituosas. "33

Accountability, portanto, está ligada à noção de boa administração. Preza para que a busca do interesse público não seja feita de forma desmedida e desarrazoada. Não basta que haja a simples gerência dos interesses da sociedade, a coisa pública deve ser gerida de forma proba e visando a maximização da eficiência e legitimidade na tutela do interesse público.

Nesse sentido, accountability traduz-se em um dever de prestação de contas do próprio Estado, na medida em que este atua a serviço da população, tem um dever para com esta de fornecer informações acerca das atividades de seus órgãos. De forma que, a usurpação ilegal de uma agência estatal por outra, e a obtenção de vantagens ilícitas de uma autoridade pública para si ou seus associados constituem violações ao conceito.

Neste contexto, a atividade participativa do cidadão é importante para requisitar do Estado essa atuação transparente e acessível. Mais uma vez, nas palavras de O'Donnell:

\footnotetext{
${ }^{32}$ MOREIRA NETO, Diogo de Figueiredo. Op. Cit. p.25-26.

${ }^{33}$ O’DONNELL, Guillermo. Accountability horizontal e novas poliarquias. São Paulo: Revista Lua Nova, No44, 1998. Disponível em <http://www.scielo.br/scielo.php?pid=S0102$\underline{64451998000200003 \& \text { script=sci arttext }>}$. Acesso em 26 de setembro de 2012.
} 
"[S]e o poder político vem de todos e se cada cidadão é ao menos potencialmente um participante na tomada de decisões coletivas, então - como em Atenas - todas as decisões devem ser públicas, no duplo sentido de que o processo que leva a elas está aberto á participação ampla e de que o conteúdo das decisões é acessível a todos. Mesmo que essas expectativas democráticas não levem diretamente à accountabilty horizontal, elas têm como conseqüencia a demanda por um alto grau de transparência na tomada de decisão política, o que tem ao menos potencialmente uma implicação anticorrupção. ",34

Em conclusão, a mudança da posição autoritária da Administração para relações em pé de igualdade com o cidadão; a ênfase do processo administrativo em detrimento ao ato; o aumento no fluxo de informações e ideias em virtude das novas tecnologias; a consolidação de uma sociedade engajada diante de novos mecanismos participativos e saída de uma posição de conformismo; bem como a afirmação do constitucionalismo agora visto como um conceito de legitimidade; colaboraram para alteração tanto da administração quanto do conceito de publicidade.

Mudou-se a concepção de que os órgãos públicos são meros detentores de informações para eles próprios, para uma noção de que eles atuam como guardiães do bem público e para tanto devem servir ao público, gerindo o interesse público de forma eficiente e proba, combatendo a corrupção e os atos ilícitos, prestando contas e proporcionando boa governança.

Assim, as informações necessitam mais do que a simples acessibilidade, elas precisam ser efetivamente compreendidas pelos cidadãos para que sejam úteis e permitam a participação da sociedade nos processos decisórios e o controle estatal, isto significa na prática linguagem simples, clara e sem excessivos termos técnicos.

A fim de garantir tal acesso e compreensão das informações pela sociedade, a Constituição da República tutela o princípio e prevê suas garantias e exceções, bem como disponibiliza mecanismos para sua efetivação, que

\footnotetext{
${ }^{34}$ Ibid.
} 
também são ratificados e incorporados pela legislação infraconstitucional. São tais garantias e mecanismos que passamos a analisar a seguir. 


\section{II - O PRINCÍPIO DA PUBLICIDADE NO ORDENAMENTO JURÍDICO BRASILEIRO}

\subsection{Legislação Constitucional}

A Constituição da República, no caput de seu art. 37, consagra o princípio da publicidade em posição de merecido destaque junto aos demais princípios reitores da administração pública:

"Art. 37. A administração pública direta e indireta de qualquer dos Poderes da União, dos Estados, do Distrito Federal e dos Municípios obedecerá aos princípios de legalidade, impessoalidade, moralidade, publicidade e eficiência (...)"

Naturalmente, por se tratar de manifestação e decorrência diretas do referido princípio, a Carta Magna tutela ainda o direito à informação. De fato, conforme previsto nos incisos XXXIII e XIV do seu art. $5^{\circ}$, é garantia concedida a todos os brasileiros e estrangeiros o direito de receber dos órgãos públicos informações de seu interesse particular, de interesse coletivo ou geral. Confira-se:

"Art. $5^{\circ}$ Todos são iguais perante a lei, sem distinção de qualquer natureza, garantindo-se aos brasileiros e aos estrangeiros residentes no País a inviolabilidade do direito à vida, à liberdade, à igualdade, à segurança e à propriedade, nos termos seguintes:

(...)

XXXIII - todos têm direito a receber dos órgãos públicos informações de seu interesse particular, ou de interesse coletivo ou geral, que serão prestadas no prazo da lei, sob pena de responsabilidade, ressalvadas aquelas cujo sigilo seja imprescindível à segurança da sociedade e do Estado 
Neste sentido, a legitimidade para pleitear a informação é ampla, podendo se tratar de pessoas físicas ou jurídicas, brasileiros ou estrangeiros. Vale destacar, também, que a natureza do interesse que enseja a obtenção da informação pode variar. Explica-se.

Quando a informação for relevante em razão de questões eminentemente pessoais, porquanto vinculadas àquele que a requer, o interesse será qualificado como privado. Se, por outro lado, for atinente a um grupo, categoria ou classe de pessoas que estão ligadas umas às outras na esteira de uma relação jurídica base, se está diante de um interesse coletivo - isto é, aquele que ultrapassa a esfera de um único indivíduo para se relacionar a toda uma coletividade específica, determinada ou determinável. Por fim, caso se trate de uma informação relevante concernente a interesses metaindividuais, ou seja, aqueles que são compartilhados por peculiaridades comuns a pessoas e situações de um mesmo gênero - sendo, portanto, abstratos e indeterminados estamos diante de um interesse geral. De todo modo, certo é que, independentemente do tipo de interesse em questão, é garantindo o direito ao seu acesso $^{35}$.

Tal direito consagra a ideia de que os órgãos públicos não detêm as informações para eles próprios. Pelo contrário, devem zelar pela guarda do bem público, sendo obrigados a disponibilizar as informações quando requeridas - quando já não o devam fazer de pronto, ex officio. Tanto é assim que, nos termos do parágrafo $2^{\circ}$, do art. 216 da CRFB/1988, incumbem à Administração a gestão da documentação governamental e as providências para franquear sua consulta a quantos dela necessitem.

Todavia, a despeito de expressa previsão constitucional, este direito restaria esvaziado se não fossem previstos concomitantemente institutos ou mecanismos que garantissem sua efetivação. Com efeito, o inciso II do parágrafo $3^{\circ}$ do art. 37 da Constituição da República estabelece que as formas 
de participação do usuário na administração pública direta e indireta, em especial o acesso dos usuários a registros administrativos e a informações sobre atos de governo, serão disciplinados por lei - neste compasso, a matéria em questão é atualmente regulada pela Lei n. 12.527/2011.

Afora a legislação regulamentadora, outros mecanismos assecuratórios do direito à informação estão previstos no próprio artigo $5^{\circ}$, inciso XXXIV, da CRFB/1988, quais sejam: os direitos de petição e de obtenção de certidões, in verbis:

"XXXIV - são a todos assegurados, independentemente do pagamento de taxas: a) o direito de petição aos Poderes Públicos em defesa de direitos ou contra ilegalidade ou abuso de poder;

b) a obtenção de certidões em repartições públicas, para defesa de direitos e esclarecimento de situações de interesse pessoal";

As certidões a que se refere o legislador constituinte não são senão a concretização física do direito à informação. Importante destacar que o termo "certidões" deve ser interpretado de forma ampla, englobando todo e qualquer documento que porventura seja de interesse da pessoa privada. São, ainda, caracterizadas pela gratuidade, podendo ser cobrado apenas o custo do serviço (quando se fizerem necessárias fotocópias, por exemplo), sendo vedada a cobrança de taxas ${ }^{36}$.

Tais documentos possibilitam a defesa e o esclarecimento de situações de cunho pessoal, sendo possíveis variações de acordo com a sua extensão (podendo ser transcrições de breve relato ou fotocópias autenticadas). Sua relevância consiste na segurança de sua validade e de sua eficácia no sentido da tutela do direito do particular de ter acesso aos seus dados pessoais segurança esta que deriva da presunção de legalidade dos atos administrativos.

\footnotetext{
${ }^{35}$ MOREIRA, Egon Bockmann. Op. Cit. p. 127-128.

${ }^{36}$ Ibid. p. $132-133$.
} 
Por oportuno, ressalte-se que eventuais consequências do desrespeito ou limitação deste direito acarretarão a responsabilização da Administração ${ }^{37}$.

Outro importante mecanismo de proteção do direito de acesso a informações é o instituto do habeas data, previsto no art. $5^{\circ}$, LXXII, da CRFB/1988 e regulamentado pela Lei n. 9.507/1997. Trata-se de remédio constitucional que possui a finalidade de assegurar (i) o conhecimento de informações relativas à pessoa do impetrante, constantes de registros ou banco de dados de entidades governamentais ou de caráter público, (ii) ou retificar dados quando não prefira fazê-lo por processo sigiloso judicial ou administrativo.

Além de disciplinar o direito de acesso à informação e prever mecanismos que o assegurem, a Constituição da República também estabelece suas limitações. Nada obstante, são poucas as exceções estabelecidas pelo art. $5^{\circ}$, LX, uma vez que a restrição legal só poderá ocorrer em situações em que houver necessidade de defesa da intimidade ou o interesse social exigir ${ }^{38}$.

No mesmo sentido, o inciso IX, do art. 93 da CRFB/1988, determina que os atos e decisões do processo haverão de ser públicos, só cabendo restrições quando estas se revelarem necessárias à intimidade do interessado e

\footnotetext{
${ }^{37}$ Ibid. p. 132.

${ }^{38}$ Neste sentido, confira-se recente decisão do TRF2: “MANDADO DE SEGURANÇA. INQUÉRITO POLICIAL. ARQUIVADO. JUÍZO DE PONDERAÇÃO. SIGILO FISCAL E BANCÁRIO. PREVALÊNCIA. DIREITO À INFORMAÇÃO. 1. As garantias individuais consagradas nos incisos X $e$ XII do art. $5^{\circ}$ da Constituição Federal não são absolutas, podendo ser mitigadas caso outros interesses públicos também garantidos constitucionalmente sejam considerados mais relevantes. 2. Para se avaliar a possibilidade de acesso à informação sigilosa, diante do interesse público envolvido, a questão deve ser analisada dentro de um sistema uno e harmônico, de maneira coordenada, preservando-se, tanto quanto possível, o conteúdo das disposições em rota de colisão, em um juízo de ponderação. 3. In casu, os autos do inquérito arquivado por ausência de indício de ilicitude contém documentos bancários e fiscais protegidos constitucionalmente, não restando caracterizada a prevalência do denominado direito público à informação sobre o direito de sigilo. 4. Apesar de ser de interesse público a licitude das operações efetuadas pelo BNDES, dar à jornalista acesso irrestrito a documentos fiscais e bancários de indivíduos considerados inocentes pelos órgãos responsáveis por investigar e punir é clara violação desarrazoada e desproporcional ao direito ao sigilo de dados do impetrante. 5. Ordem concedida para garantir ao impetrante o direito de não ter divulgado o conteúdo dos documentos protegidos por sigilo, reformando, em consequência, a decisão de fls. 111/112, proferida nos autos do processo $n^{o}$ 2006.51.01.509435-2." (TRF2, MS 201102010172093, $2^{a}$ Turma Especializada, Rel.: Desembargadora Federal Liliane Roriz, j.22/05/2012, publ.:02/08/2012).
} 
somente quando não prejudiquem o interesse público. Na hipótese de um processo correr sob sigilo, ao próprio interessado e a seus procuradores é garantido o pleno direito de acesso aos autos e à sessão de julgamento. De forma complementar, o inciso $\mathrm{X}$ do mesmo artigo disciplina a necessidade de motivação das decisões, uma vez que sua ausência é forma reflexa de frustração da regular incidência do princípio da publicidade.

Diante do exposto, verifica-se que o princípio da publicidade é um princípio reitor da administração pública e que sua consequência direta é o direito de acesso às informações, reconhecidamente um direito fundamental e essencial para a implementação do próprio Estado Democrático de Direito.

Ocorre que, a despeito de se encontrar amplamente amparado na Constituição da República, para que o referido direito seja efetivamente respeitado e observado, faz-se necessária também a sua regulamentação em legislação infraconstitucional.

\subsection{Legislação Infraconstitucional}

Como cediço, o princípio da publicidade previsto na CRFB/1988 repercute em diversos dispositivos infraconstitucionais, que determinam prazos e formas de publicização de atos administrativos. Por se tratar de um princípio eminentemente prático, restaria esvaziado caso não fossem previstas formas concretas de se demandar prestações efetivas da Administração.

De início, é imprescindível destacar seus reflexos diretos na notória e relevante Lei n. 9.784/1999, que regulamenta o processo administrativo em âmbito federal e, supletivamente, nos demais entes federativos. O referido marco legal observa o princípio da publicidade de forma expressa ao determinar, em seu art. $2^{\circ}$, parágrafo único, V, que a Administração Pública deverá promover a divulgação oficial dos seus atos administrativos, ressalvadas apenas as hipóteses de sigilo previstas na Constituição. 
No mesmo compasso, o mencionado diploma garante, em seu art. $3^{\circ}$, II, o direito do administrado à ciência da tramitação dos processos administrativos em que ostente a condição de interessado, podendo, para tanto, (i) ter vista dos autos, (ii) obter cópias de documentos neles contidos e (iii) tomar conhecimento das decisões proferidas. É o art. $9^{\circ}$ da mencionada Lei quem se encarrega de definir a extensão do termo "interessados", que engloba tanto pessoas físicas quanto pessoas jurídicas titulares de direitos ou interesses individuais que tenham iniciado o processo, ou, alternativamente, aqueles que possam ser afetados pela decisão adotada. Abrange, ainda, organizações e associações representativas em defesa de direitos e interesses coletivos ou difusos.

Como se pode depreender do referido dispositivo legal, a intenção do legislador pátrio foi clara: ampliar o acesso da forma mais abrangente possível a todos os eventuais interessados nas decisões administrativas. Neste diapasão, tal previsão deve ser combinada com o art. 46 da mesma Lei, que garante o direito à vista do inteiro teor processual e à obtenção de certidões ou cópias correlatas, vedada, todavia, a divulgação de dados e documentos de terceiros protegidos por sigilo ou pelo direito à privacidade, à honra ou à imagem, sempre em obediência às restrições constitucionais.

Mais do que isso, é importante que seja observada a forma de divulgação dos atos previstos na lei, sob pena de sua publicidade não ser efetiva. De fato, a regra é que, ao menos em relação às pessoas envolvidas no processo, a publicidade deve ser eficaz e anterior à execução dos atos, de sorte a se evitar que o processo seja exclusivamente conduzido pela Administração e que, somente ao final, seja dada mera ciência aos interessados de seu resultado ${ }^{39}$.

Nesse bojo, cumpre ressaltar que o Direito Administrativo contemporâneo não se satisfaz apenas com a vetusta prática unilateral dos atos 
administrativos: passa-se por um período de processualização das práticas administrativas, movimento este que conduz à superação dos atos unilaterais e autoritários em prol dos processos administrativos e de todos os mecanismos de promoção da participação a ele inerentes.

Na verdade, não basta, em um Estado Democrático de Direito, a simples emanação da vontade final do Estado, fazendo-se mister também a divulgação de todo o iter processual que lhe deu causa. Somente dessa forma é possível que os administrados logrem ter efetiva ciência das decisões administrativas, bem como possam influenciar na produção dos próprios atos administrativos.

Prosseguindo com a análise da Lei de Processo Administrativo Federal, é de se salientar que o art. $26, \S 3^{\circ}$, prevê a intimação pessoal do interessado para a tomada de ciência de decisões prolatadas - ou mesmo para a efetivação de eventuais diligências requeridas - com antecedência mínima de 3 (três) dias úteis, ressalvada a hipótese de seu parágrafo $4^{\circ}$, que faculta a intimação por edital quando se tratar de interessados indeterminados, desconhecidos ou com domicílio indefinido.

Já no que tange ao procedimento licitatório, a Lei n. 8.666/1993 determina a publicação antecipada dos editais em diário oficial e em jornais de grande circulação. No caso específico das licitações na modalidade convite, deverá ocorrer a afixação do instrumento convocatório em local apropriado. Já na hipótese da modalidade pregão, disciplinada pela Lei n. 10.520/2002, a divulgação varia em função do valor da contratação, podendo ser feita por meio de diário oficial, jornal de grande circulação ou mesmo por meio da internet - inovação esta que se coaduna perfeitamente com a celeridade característica de tal modalidade licitatória.

Ainda no campo dos contratos administrativos, verifica-se que o princípio da publicidade é ratificado no art. 14 da Lei n. 8.987/1995,

\footnotetext{
${ }^{39}$ MOREIRA, Egon Bockmann. Op. Cit. p.135.
} 
dispositivo que determina sua estrita observância nas concessões e permissões de serviços públicos.

A Lei n. 9.051/1995, ao seu turno, possui apenas quatro artigos e dispõe sobre a expedição de certidões para a defesa de direitos e esclarecimentos de situações. Estabelece, basicamente, que o prazo para expedição de certidões requeridas aos órgãos da administração centralizada ou autárquica, às empresas públicas, às sociedades de economia mista e às fundações públicas da União, dos Estados, do Distrito Federal e dos Municípios, é de 15 (quinze) dias, contados do registro do pedido no órgão expedidor e improrrogáveis.

De outra banda, a Lei n. 8.159/1991 dispõe sobre a política nacional de arquivos públicos e privados e teve seu capítulo $\mathrm{V}$, relativo ao acesso e ao sigilo dos documentos públicos, revogado pela recente Lei n. 12.527/2011. Com efeito, é o Decreto $n^{\circ} 4.073 / 2002$ - que regulamenta a supramencionada Lei n. 8.159/1991 -, que dispõe sobre o armazenamento e a gestão de documentos públicos, regulamentando tanto o Sistema Nacional de Arquivos (SINAR), como também seu órgão central, o Conselho Nacional de Arquivos (CONARQ). Este último tem por finalidade definir a política nacional de arquivos públicos e privados e exercer orientação normativa visando à gestão e à proteção especial dos documentos, bem como regulamentar suas competências, composição e funcionamento.

Neste contexto, o Decreto n. 4.553/2002 dispõe, no âmbito da Administração Pública Federal, sobre a salvaguarda de dados, informações, documentos e materiais sigilosos de interesse da segurança da sociedade e do Estado, estabelecendo a classificação, o grau e o prazo do sigilo. Em caráter complementar, o Decreto n. 5.301/2004 institui a Comissão de Averiguação e Análise de Informações Sigilosas.

Há de ser dado, ainda, o merecido destaque à Lei Complementar n. 101/2000 (Lei de Responsabilidade Fiscal), que contempla importantes instrumentos para o controle da transparência e da fiscalização das finanças 
públicas que vêm impactando positiva e consistentemente a forma de gestão da coisa pública. Confira-se:

“Art. 48. São instrumentos de transparência da gestão fiscal, aos quais será dada ampla divulgação, inclusive em meios eletrônicos de acesso público: os planos, orçamentos e leis de diretrizes orçamentárias; as prestações de contas e o respectivo parecer prévio; o Relatório Resumido da Execução Orçamentária e o Relatório de Gestão Fiscal; e as versões simplificadas desses documentos."

Por fim, ainda como materialização do princípio da publicidade na seara infraconstitucional, registre-se que a Lei n. 9.605/1998, ao dispor sobre as sanções penais e administrativas derivadas de condutas e atividades lesivas ao meio ambiente, autoriza que os órgãos ambientais integrantes do Sistema Nacional do Meio Ambiente (SISNAMA) - responsáveis pela execução de programas e projetos e pelo controle e fiscalização dos estabelecimentos e das atividades suscetíveis de degradar a qualidade ambiental - celebrem com força de título executivo extrajudicial termos de compromisso com pessoas físicas ou jurídicas responsáveis por atividades reputadas efetiva ou potencialmente poluidoras. Tais termos de compromisso, por expressa determinação do seu art. 79-A, $\S 8^{\circ}$, hão de ser publicados no órgão oficial competente, sob pena inexorável de ineficácia.

Como se vê, a legislação que incorpora o espírito da publicidade em sede administrativa é bastante esparsa, havendo algumas razões para tanto. A maior delas diz respeito à própria dificuldade de codificação do Direito Administrativo, cujo escopo é diversificado e se sujeita a variações recorrentes oriundas das alterações políticas, sociais e econômicas, que inviabilizam sua consolidação em um único texto.

Talvez por isso, não se pode deixar de notar que, embora robusto, o arcabouço normativo inspirado no norte axiológico da publicidade também padece de defeitos e lacunas. 
Assim, a Lei de Responsabilidade Fiscal, em que pese ter previsto a disponibilização em tempo real para a população de uma grande quantidade de informações atualizadas, não foi cautelosa em determinar a forma e qualidade da publicação de tais dados. A Lei Ambiental supramencionada, de igual forma, mostrou-se "insuficiente em relação à quantidade de informações que determinava que fossem espontaneamente publicadas pelos órgãos abrangidos pela Lei ${ }^{, 40}$.

Ainda quanto às deficiências, note-se que a Lei de Arquivos Públicos (Lei n. 8.159/1991), juntamente com a revogada Lei n. 11.111/2005, pecou em não fornecer detalhes acerca da estrutura e da organização interna das informações governamentais públicas ou sigilosas, na medida em que se limitou a relegar tal tarefa a atos normativos regulamentadores ou mesmo ao gestor estatal. $^{41}$

Sob o prisma de tais falhas legislativas, pode-se concluir que não havia na prática uma norma que regulamentasse de modo efetivo o direito ao acesso à informação insculpido no art. $5^{\circ}$, XXXIII, in fine, uma vez que a Lei $n$. 11.111/2005 regulamentava única e tão somente o sigilo das informações governamentais. Esta ausência de previsão legal específica ou sequer de instrumentos jurídicos que assegurassem a qualidade, o conteúdo e a organização das informações, fatalmente resultava na fragilização do aludido direito constitucional.

Com efeito, até o advento da Lei n. 12.527/2011, cuja inovação legislativa será mais bem delineada no capítulo subsequente, o acesso à informação não havia sido devidamente regulamentado. E isto a despeito de o art. 5, XXXIII, da CRFB/1988, não apenas prever o direito ao acesso à informação, como também determinar a criação de lei específica para sua regulamentação.

40 PAES, Eneida Bastos. A Construção da Lei de Acesso à Informação Pública no Brasil: desafios na implementação de seus princípios. Revista do Serviço Público. Brasília out/dez 2011. p.411. 
A delegação, promovida pelo legislador de então, da regulamentação de prazos e procedimentos aos decretos e outros normativos infralegais, além de incorrer em eventual inconstitucionalidade, poderia conduzir à excessiva e indesejável intervenção política e administrativa, abrindo uma brecha para o controle ou a direção do conteúdo da informação.

Desta forma, ante a legislação esparsa e pouco aprofundada da matéria, que consequentemente prejudicava a consecução do direito ao acesso a informações, para além da manifesta necessidade de adaptação às novas tendências mundiais que cada vez mais privilegiam o princípio da publicidade dos atos públicos, tornou-se imperiosa e imprescindível a edição da chamada Lei de Acesso à Informação no Brasil (LAI).

${ }^{41}$ Ibid. 


\section{III - DIREITO À INFORMAÇÃO: Alterações trazidas pela Lei}

\section{$12.527 / 2011$}

\subsection{Contexto Global da Lei}

A edição da recente Lei n. 12.527, de 18 de novembro de 2012, que dispõe sobre acesso a informações, pode ser melhor compreendida quando analisada dentro do contexto de padrões e tendências internacionais de transparência e acessibilidade de informações.

Conforme já abordado, o acesso a informações é instrumento fundamental para a consolidação da democracia. Isto porque a democracia, diferentemente de como era pensada nos séculos passados - decorrente de uma divindade ou princípio - adquire cada vez mais um caráter prático, que se traduz em formas de controle público do exercício de poder. Essa transição é descrita por John Keane, em seu livro intitulado "Vida e Morte da Democracia":

“(...) a democracia começa a ser considerada de modo muito mais pragmático, como uma arma acessível e indispensável, contra concentrações de poder irresponsável e contra os efeitos danosos desse poder. Na nova era da democracia que está surgindo, o próprio mundo passa a ter um novo significado. Este se refere ao escrutínio e ao controle público dos tomadores de decisões, quer eles operem na área de instituições nacionais ou internacionais, nas chamadas organizações não governamentais ou em sociedades civis tais como empreendimento de negócios, sindicatos, associações esportivas e filantrópicas. "42

Nesse sentido, o autor sustenta o curso de uma transformação da democracia política para uma "democracia monitória", na qual se multiplicam os mecanismos de monitoramento e vigia dos poderes estabelecidos,

\footnotetext{
${ }^{42}$ KEANE, John. Vida e Morte da Democracia. 70ª Ed. São Paulo: Almedina, 2010. p. 26.
} 
permitindo que a sociedade seja adequadamente informada sobre seu funcionamento. Nas palavras de Keane:

“(...) a forma histórica emergente da democracia 'monitória' é uma forma 'pós-Westminister' de democracia na qual instrumentos de monitoração de poder e de controle de poder começaram a se estender para os lados e para baixo através de toda a ordem política. Eles penetram nos corredores do governo e ocupam os esconderijos e as fissuras da sociedade civil e ao fazerem isso complicam enormemente e, algumas vezes, embaraçam as vidas de políticos, partidos, legislaturas e governos. Essas instituições extraparlamentares de monitoração de poder incluem - para mencionar aleatoriamente apenas algumas poucas - comissões de integridade pública, ativismo judiciário, tribunais locais, tribunais no lugar de trabalho, conferências de consenso, parlamentos para minorias, litígios, inquéritos públicos independentes, grupos de especialistas na solução de problemas, relatórios de peritos, orçamentos participativos, vigílias, blogging e outras formas de escrutínio na mídia., ${ }^{43}$

Nos últimos 30 (trinta) anos, com as novas Constituições democráticas e mecanismos de tecnologia vem-se intensificando os movimentos a favor da transparência e combate à corrupção. As Constituições modernas passaram a incluir o acesso a informação como uma garantia fundamental à democracia. Nesse diapasão, nos últimos anos aumentou consideravelmente o número de legislações que efetivam este direito ${ }^{44}$.

Paralelamente, a nova era tecnológica intensificou o livre fluxo das informações e trouxe facilidades para o cidadão no que tange ao acesso, controle e cobrança de seus dirigentes.

O Brasil, por sua vez, iniciou seu movimento interno de transparência com a adoção de algumas medidas de combate e prevenção à corrupção, com destaque para o Portal da Transparência (previsto no Decreto $\mathrm{n}^{\circ}$ 5.482/2005),

\footnotetext{
${ }^{43}$ Ibid. p. 27.

44 MENDEL, Toby. Liberdade de informação: um estudo de direito comparado. $2^{\mathrm{a}}$ d. Brasília: UNESCO, 2009. p. 3.
} 
mantido pela Controladoria Geral da União (CGU), que divulga, diariamente, todos os gastos de todos os órgãos públicos federais.

As ações adotadas pelo governo brasileiro repercutiram no cenário internacional. Tanto é assim que o Brasil foi o primeiro país convidado pelo Presidente Barack Obama a fazer parte da Parceria para Governo Aberto (Open Government Partnership) $)^{45}$.

A ideia da criação da referida parceria foi lançada pelo Presidente norte americano em setembro de 2010 na 65 ${ }^{\mathrm{a}}$ Assembleia Geral da ONU. A Parceria de Governo Aberto foi elaborada com o objetivo de difundir e incentivar as práticas governamentais de transparência e combate à corrupção. $\mathrm{O}$ foco da iniciativa foi justamente a abertura de informações à população, ao jornalismo investigativo e aos órgãos externos de controle, que no Brasil são o Ministério Público e os Tribunais de Contas.

Posteriormente, foram convidados outros 6 (seis) países para fazer parte do grupo inicial (Estado do Reino Unido, África do Sul, Filipinas, Indonésia, México e Noruega). Atualmente, o Brasil e os EUA copresidem a parceria e cerca de 70 (setenta) países e mais de 40 (quarenta) organizações nãogovernamentais almejam o ingresso ${ }^{46}$.

É importante ressaltar que a iniciativa consiste em uma participação voluntária, não sendo propriamente um tratado internacional, tampouco uma convenção. Em verdade, os países integrantes se dispuseram a providenciar medidas que ultrapassam as previsões das convenções que fazem parte, com intuito de promover um governo aberto.

\footnotetext{
${ }^{45}$ Entrevista do Ministro-Chefe da Controladoria Geral da União, Jorge Hage, ao programa Bom Dia Ministro transmitido em 30/08/2012. Disponível em <http://www.cgu.gov.br/Ministro/ArtigosEntrevistas/itens/entrevista_20120830_JorgeHage_Radio Nacional_AM.asp>. Acesso em 27 de outubro de 2012.

${ }^{46}$ Assessoria de Comunicação Social da CGU , "Hage participa, nos EUA, do lançamento da Parceria para Governo Aberto". Disponível em <http://www.cgu.gov.br/Imprensa/Noticias/2011/noticia16611.asp >. Acesso em 27 de outubro de 2012.
} 
Os compromissos não são padronizados, nem de adoção obrigatória. Pelo contrário, cada país é responsável por elaborar seus planos de ação conforme suas circunstâncias, realidade, sistema jurídico e interesses, adotando aquelas medidas que melhor puderem atender às suas necessidades, desde que enquadradas nas diretrizes da Parceria.

Os critérios para ingressar na Parceria são 4 (quatro): (i) transparência fiscal, (ii) acesso à informação, (iii) divulgações sobre políticos eleitos ou cargos públicos de alto escalão e (iv) engajamento do cidadão.

Neste contexto, a Lei de Acesso à Informação foi elaborada como uma das metas no Plano de Ação do Governo Brasileiro na Parceria de Governo Aberto. Com a sua implementação, o Brasil conseguiu abranger ao menos os três primeiros requisitos.

Deste modo, diante de (i) movimentos internacionais a favor da transparência pública e combate a corrupção; (ii) elaboração de dispositivos legais regulamentadores do direito de acesso a informação em diversos países reconhecendo tal direito como fundamental ao indivíduo e essencial para garantia e consolidação dos regimes democráticos; e (iii) a ausência na

legislação nacional de regulamentação sistemática e unitária que assegurasse efetivamente o acesso amplo a informações e documentos produzidos pela Administração Pública, considerou-se necessária a elaboração de uma lei que disciplinasse e garantisse tal direito. Foi exatamente nesse cenário que foi editada a Lei n. 12.527/2011.

\subsection{Inovações trazidas pela Lei}

\subsubsection{Panorama Geral e Noções Principais da Lei}

A Lei n. 12.527/2011 é uma lei ordinária federal. No entanto, seu âmbito de aplicação engloba todos os entes públicos nacionais, o que a reveste 
de caráter nacional. Foi sancionada em 18/11/2011 e entrou em vigor em 16/05/2012, após o prazo de vacância de 180 (cento e oitenta) dias. Nesta mesma data foi publicado o Decreto n. 7.724/2012, que regulamenta, no âmbito do Poder Executivo Federal, os procedimentos para a garantia do acesso à informação e para a classificação de informações sob restrição de acesso, observados grau e prazo de sigilo.

A Lei regulamenta o acesso a informações previsto no art. $5^{\circ}$, XXXIII, art. $37 \S 3^{\circ}$, II e art. $216 \S 2^{\circ}$, todos da Constituição da República. Além de regulamentar os dispositivos constitucionais, revogou expressamente a Lei $\mathrm{n}$. 11.111/2005, que disciplinava a parte final do art. $5^{\circ}$, XXXIII e dispositivos da Lei n. 8.159/1991 (que trata da política nacional de arquivos públicos e privados). Ademais, traz algumas modificações para o regime dos servidores públicos federais (Lei n. 8.112/1990).

Ao contrário da lei antiga (Lei n. 11.111/2005), que era incipiente e só tinha 8 (oito) artigos, a nova lei busca de forma sistemática e unitária trazer mecanismos efetivos para garantir o acesso à informação, ao mesmo tempo em que estabelece critérios claros para as exceções. Ainda neste contexto, é importante ressaltar que a Lei possui a preocupação de promover ideais de transparência, celeridade e responsabilidade que devem nortear a relação entre o Estado e o cidadão.

A principal garantia constituída no diploma é o acesso pleno, imediato e gratuito às informações. Para tanto, estabelece-se a desnecessidade de qualquer justificativa de pedidos de acesso, e consagra-se a ideia central de promoção da publicidade como regra, sendo o sigilo a exceção.

Nesta toada, utiliza-se de meios variados, com destaque para internet, com divulgação obrigatória. Prevê ainda a criação de Serviços de Informação ao Cidadão (SICs). A disponibilização de informações por meio digital será possível quando houver anuência do interessado, justamente para garantir a celeridade e efetividade da demanda e reduzir seu custo. 
Além de englobar todos os entes - União, Estados, Distrito Federal e Município - e ser aplicável aos três poderes, vincula as entidades privadas sem fins lucrativos que recebam recursos públicos.

No que tange à transparência, a lei traduz uma preocupação em relação à qualidade da informação transmitida. Conforme já tratado no primeiro capítulo, a publicidade não se limita a uma divulgação pura e simples dos atos administrativos, mas deve ser entendida de forma a viabilizar a correta e efetiva compreensão dos atos pelo homem médio. Nesse sentido, a Lei determina que as informações sejam traduzidas para linguagem de fácil compreensão, e quando necessário deverão ser feitas adaptações cabíveis para alcançar tal objetivo.

Ainda em relação à transparência, a LAI traz uma importante inovação. Ela divide o conceito em duas esferas distintas: transparência passiva e transparência ativa. A primeira consiste no fornecimento de informações mediante requerimento. Nesse caso, o órgão se manifestará quando for requisitado. A segunda se traduz na obrigatoriedade dos órgãos divulgarem certas informações de forma proativa e rotineira, quando se tratar de assuntos de interesse público. Esta divisão é relevante na medida em que é vedada a inércia do órgão: ainda que não lhe seja dirigida uma requisição específica, pelo simples fato de receber recursos públicos, terá o dever de prestar contas e dar esclarecimentos acerca de suas atividades. Nesse contexto, a Lei define as matérias específicas em que decorre tal obrigação.

Considerando a premissa da publicidade como regra, a recusa ao acesso só será permitida mediante decisão devidamente fundamentada. Nesta linha, garante-se o acesso ao inteiro teor da decisão denegatória, bem como o direito a recurso, devendo a referida decisão indicar os procedimentos para o recurso, como prazo e autoridade competente.

A Lei é cautelosa na delimitação das exceções, que se restringem às informações pessoais e sigilosas, compreendidas apenas naquelas 
imprescindíveis à segurança da sociedade e do Estado. São definidos também os critérios de proteção dessas informações pessoais e sigilosas, assim como as autoridades competentes para sua classificação. A Lei diminui os prazos das informações sigilosas, previstos na legislação anterior, e limita a apenas uma renovação. No caso de o documento ser apenas parcialmente sigiloso, é garantido o acesso à parte não sigilosa.

Fora isso, a Lei exige uma aferição constante da existência das razões que justificaram a restrição de acesso, obrigando os órgãos e entidades públicas a revisarem, periodicamente, as informações classificadas como sigilosas, de modo a decidir sobre a necessidade de manutenção de sigilo. Ela também define os recursos e as penalidades para os agentes que descumprirem a lei.

Em linhas gerais, estas são as principais alterações trazidas pelo diploma, passa-se agora para análise dos dispositivos mais importantes e especificidades da lei.

\subsubsection{Estrutura e Dispositivos da Lei}

\subsubsection{Disposições Gerais}

Feito esse panorama geral da Lei, passa-se agora a uma análise pormenorizada dos dispositivos.

Os artigos $1^{\circ}$ e $2^{\circ}$ da LAI tratam das disposições gerais. $\mathrm{O}$ art. $1^{\circ}$ dispõe que os procedimentos deverão ser observados pela União, Estado, Distrito Federal e Municípios. A Lei subordina os três poderes federativos, incluindo o Tribunal de Contas e o Ministério Público, e se aplica tanto a Administração direta quanto à indireta. Já o art. $2^{\circ}$ traz uma disposição importante, a qual determina que sua aplicação engloba as entidades privadas sem fins lucrativos que recebam recursos públicos. Assim, estes particulares que recebam recursos 
públicos ou estejam vinculados por alguma forma contratual ao Poder Público também são obrigados a fornecer as informações previstas na Lei.

\subsubsection{Garantias do Direito ao Acesso}

Os artigos $3^{\circ}, 6^{\circ}$ e $7^{\circ}$ trazem as garantias e princípios que se destinam a assegurar o correto exercício do direito fundamental de acesso à informação. A característica principal da Lei é a consagração da ideia da publicidade como regra, sendo o sigilo exceção. Neste passo, determina que as informações relevantes ao interesse público sejam divulgadas independentemente de solicitações, e a divulgação deverá ocorrer por diversos meios de comunicação, inclusive utilizando-se novas tecnologias.

Vale salientar, por oportuno, o papel da Lei no fomento de uma cultura de transparência e controle social da administração publica, enfatizada no arts. $3^{\circ}$, IV e $6^{\circ}$, I, que se traduz no amplo acesso e divulgação da informação assegurada sua proteção, especialmente quando se tratar de informação sigilosa e pessoal, e garantida sua disponibilidade, autenticidade e integridade - bem como a utilização de linguagem de fácil compreensão, expressamente determinada no art. $5^{\circ}$. Tais esforços representam uma mudança cultural na atuação administrativa como um todo.

De mais a mais, a LAI também busca assegurar a orientação sobre os procedimentos de acesso, bem como o local onde poderá ser encontrada a informação desejada. É garantido o acesso à informação primária, íntegra, autêntica e atualizada, contida em registros ou documentos produzidos ou acumulados por órgãos ou entidades, recolhidos ou não a arquivos públicos. Vale ressaltar que, se a informação for produzida ou custodiada por pessoa física ou entidade privada, em decorrência de qualquer vínculo com órgãos ou entidades públicas, será garantido o seu acesso, ainda que tal vínculo já tenha cessado. 
A Lei apresenta também matérias específicas, em que o acesso é garantido. O direito ao acesso é expressamente assegurado pela LAI quando o assunto for referente: (i) às atividades exercidas pelos órgãos e entidades inclusive sobre sua política, organização, serviços; (ii) à administração do patrimônio público, utilização de recursos públicos, licitação, contratos administrativos; (iii) à implementação, acompanhamento e resultados dos programas, projetos e ações dos órgãos e entidades públicas, bem como metas e indicadores propostos; ou ainda (iv) ao resultado de inspeções, auditorias, prestações e tomadas de contas realizadas pelos órgãos de controle interno e externo, incluindo prestações de contas relativas a exercícios anteriores.

Contudo, o $\operatorname{art.} 7^{\circ} \S 1^{\circ}$, excepciona as informações referentes a projetos de pesquisa e desenvolvimento científicos ou tecnológicos cujo sigilo seja imprescindível à segurança da sociedade e do Estado. Caso não seja autorizado o acesso integral, assegura-se o acesso à parte não sigilosa por meio de certidão, extrato ou cópia com ocultação da parte sob sigilo.

Por sua vez, o artigo $7^{\circ}, \S 3^{\circ}$, dispõe o seguinte:

"Art $7 \S 3 \underline{O}$ O direito de acesso aos documentos ou às informações neles contidas utilizados como fundamento da tomada de decisão e do ato administrativo será assegurado com a edição do ato decisório respectivo."

Tal artigo é capaz de gerar controvérsias na medida em que uma primeira leitura permite a interpretação de que o acesso a documentos e informações que foram utilizados como fundamento para a adoção de determinada decisão do poder publico só poderia ocorrer após a expedição ou decisão final do ato. Ocorre, no entanto, que não seria plausível impor ao interessado tal impedimento. Desta forma, a interpretação mais razoável é no sentido de que, além da decisão propriamente dita, o interessado também terá 
pleno acesso aos documentos e informações que fundamentaram a sua $\operatorname{adoção~}^{47}$. Neste sentido, o Decreto n. 7.724/12 disciplina em seu artigo 20:

"Art. 20. O acesso a documento preparatório ou informação nele contida, utilizados como fundamento de tomada de decisão ou de ato administrativo, será assegurado a partir da edição do ato ou decisão."

\subsubsection{Definições}

A fim de garantir a efetividade do direito e evitar que as informações sejam de algum modo deturpadas, o art. $4^{\circ}$ traz um rol de definições legais relevantes para a correta aplicação da lei. O inciso I define informação como:

"Art.4": Para efeitos desta Lei, considera-se:

I - Informação: dados, processados ou não, que podem ser utilizados para produção e transmissão de conhecimento, contidos em qualquer meio, suporte ou formato;"

Os últimos quatro incisos se referem a qualidades da informação prestada. A "disponibilidade" se refere à possibilidade da informação ser conhecida e utilizada por indivíduos, equipamentos ou sistemas autorizados. Por sua vez, a "autenticidade" é relativa à procedência da informação, produzida, expedida, recebida ou modificada por determinado indivíduo, equipamento ou sistema. A "integridade" refere-se a não modificação da informação quanto à origem, trânsito e destino. Por último, a "primariedade" consiste na coleta na fonte, com o máximo de detalhamento possível, sem modificações.

\footnotetext{
${ }^{47}$ CARDOSO, André Guskow. $O$ direito de acesso a informações: panorama derivado da Lei $\mathrm{n}^{\circ}$ 12.527, 18 de novembro de 2011. Informativo Justen, Pereira, Oliveira, Talamini, Curitiba, $\mathrm{n}^{\circ}$ 63, $\begin{array}{llll}\text { maio de } & 2012 . & \text { Disponível em }\end{array}$ $\langle$ http://www.justen.com.br//informativo.php?informativo $=63 \& \operatorname{artigo}=653>$. Acesso em 26 de junho de 2012.
} 


\subsubsection{Divulgação proativa de informações}

Ademais, os artigos $8^{\circ}$ e $9^{\circ}$ dispõem acerca das regras sobre a divulgação rotineira e proativa de informações. Neste ponto, convém lembrar que a Lei trabalha com dois conceitos de transparência distintos.

A transparência ativa se traduz na obrigação mínima do órgão de divulgação permanente de determinadas informações. Assim, quando se tratar de dados que o órgão público entenda ser de interesse da população, sua divulgação ocorrerá de forma espontânea.

Por outro lado, a transparência passiva é aquela em que a divulgação ocorre mediante demanda. É formulada uma solicitação feita pelo cidadão que deve cumprir o procedimento padrão estabelecido pela Lei para a obtenção das informações que deseja. Mais adiante será explicitado o procedimento em questão, bem como os recursos e penalidades para os agentes públicos que não cumprirem os mandamentos legais.

O parágrafo primeiro do art. $8^{\circ}$ elenca o rol de divulgação mínimo que deve ser observado pelos órgãos e entidades públicas:

"Art. $8^{o}$ É dever dos órgãos e entidades públicas promover, independentemente de requerimentos, a divulgação em local de fácil acesso, no âmbito de suas competências, de informações de interesse coletivo ou geral por eles produzidas ou custodiadas.

$\S 1^{o} \mathrm{Na}$ divulgação das informações a que se refere o caput, deverão constar, no mínimo:

I - registro das competências e estrutura organizacional, endereços e telefones das respectivas unidades e horários de atendimento ao público;

II - registros de quaisquer repasses ou transferências de recursos financeiros;

III - registros das despesas;

IV - informações concernentes a procedimentos licitatórios, inclusive os respectivos editais e resultados, bem como a todos os contratos celebrados;

$V$ - dados gerais para o acompanhamento de programas, ações, projetos e obras de órgãos e entidades; $e$

VI - respostas a perguntas mais frequentes da sociedade." 
Para a divulgação de tais informações, a LAI determina que sejam utilizados todos os meios e instrumentos legítimos, sendo obrigatória a divulgação nos sítios oficiais. Ela ainda estabelece parâmetros que os sites devem atender, como ferramentas de pesquisa e linguagem de fácil compreensão. Interessante que ela dispõe que deve ser possível a gravação de relatórios em diversos formatos eletrônicos. No entanto, prevê a dispensa de divulgação na internet para os Municípios com população de até 10 (dez) mil habitantes.

Além da divulgação obrigatória por meio eletrônico, o art. $9^{\circ}$ prevê a criação dos Serviços de Informação ao Cidadão (SIC) nos órgãos e entidades do poder público:

"Art. $9^{\circ} \mathrm{O}$ acesso a informações públicas será assegurado mediante:

I - criação de serviço de informações ao cidadão, nos órgãos e entidades do poder público, em local com condições apropriadas para:

a) atender e orientar o público quanto ao acesso a informações;

b) informar sobre a tramitação de documentos nas suas respectivas unidades;

c) protocolizar documentos e requerimentos de acesso a informações; $e$ II - realização de audiências ou consultas públicas, incentivo à participação popular ou a outras formas de divulgação."

Todas essas determinações são relativas à operacionalização do poder público para o fornecimento de informações para os interessados. De modo geral, é possível verificar a preocupação da Lei em detalhar os deveres a obrigações dos órgãos, bem como sua forma de atuar, o que a distingue das legislações anteriores, que não estabeleciam de maneira clara a forma como a informação deveria ser disponibilizada aos interessados. 


\subsubsection{Processamento dos pedidos de informação}

Os arts. $10^{\circ}$ a 14 tratam do processamento de pedidos de informação. No caso do interessado necessitar de informações que não são divulgadas rotineiramente, a Lei prevê a possibilidade de sua requisição.

Qualquer interessado poderá apresentar pedido de acesso a informações por qualquer meio legítimo - inclusive pelos sítios oficiais na internet, sendo obrigação dos órgãos e entidades viabilizar tal alternativa - devendo o pedido conter apenas a identificação do requerente e especificação da informação requerida. Nesta toada, a LAI veda quaisquer exigências relativas à identificação do requerente que inviabilizem a solicitação, bem como outras que versem sobre os motivos determinantes desta, ou seja, não é necessário que seja formulada justificativa para o acesso à informação sob pena de se restringir o direito.

A Lei disciplina ainda que o órgão ou entidade pública deverá autorizar ou conceder acesso imediato à informação disponível. Quando isto não for possível, o prazo do órgão ou entidade não poderá ultrapassar 20 (vinte) dias no entanto, é permitida uma prorrogação por 10 (dez) dias mediante justificativa expressa que deverá ser comunicada ao requerente. Findo este prazo o detentor da informação deverá adotar uma das seguintes condutas: (i) comunicar a data, local e modo para se realizar a consulta, efetuar a reprodução ou obter a certidão; (ii) indicar as razões de fato ou de direito da recusa, total ou parcial, do acesso pretendido; ou (iii) comunicar que não possui a informação, indicar, se for do seu conhecimento, o órgão ou a entidade que a detém, ou, ainda, remeter o requerimento a esse órgão ou entidade, cientificando o interessado da remessa.

$\mathrm{O}$ art. $11, \S 3^{\circ}$, faculta ao órgão ou entidade que sejam oferecidos meios para que o próprio requerente possa pesquisar a informação de que necessitar. Vale ressaltar, que isto não significa a transferência do ônus de localizar para o 
requerente - até mesmo porque muitas vezes o banco de dados dos arquivos de tais autoridades é tão vasto que a localização da informação poderia traduzir-se em sua negativa. Tal faculdade é prevista para situações nas quais a atuação do solicitante não represente restrição ao amplo acesso ${ }^{48}$.

Valendo-se da tecnologia para ampliar e facilitar os meios de acesso, a Lei prevê a possibilidade de fornecimento da informação em formato digital quando ela esteja sob esta forma de armazenamento, devendo, para tanto, haver anuência do interessado. Ademais, prevê uma forma de desobrigar o requerido do fornecimento direto quando a informação solicitada estiver à disposição do público em formato impresso, eletrônico ou outro meio universal, devendo apenas informar o lugar e forma para sua consulta, obtenção ou reprodução - excepciona-se tal hipótese no caso de o requerente declarar que não possui meios para realizar por si só tais procedimentos.

Em relação às informações contidas em documentos cuja manipulação possa prejudicar a integridade do documento, será oferecida a consulta de cópia, com certificação de que esta confere com o original.

Ressalta-se que é garantida a gratuidade do serviço de busca e fornecimento de informações, sendo permitida somente a cobrança do valor necessário ao ressarcimento do custo dos serviços e dos materiais utilizados no caso de reprodução de documentos. Ainda neste caso, se o requerente não possuir condições para tanto estará isento da restituição.

Quando se tratar de informação total ou parcialmente sigilosa o acesso poderá ser negado. Em tal hipótese a negativa deverá ser devidamente motivada (facultado ao interessado o acesso ao inteiro teor) e informada ao requerente, bem como a possibilidade de recurso, seus prazos, condições e entidade competente para apreciação.

${ }^{48}$ Ibid. 


\subsubsection{Recursos e Comissão Mista de Reavaliação de Informações}

Os artigos 15 a 20 regulamentam o procedimento dos recursos. Contra decisões de indeferimento de acesso a informações caberá recurso no prazo de 10 (dez) dias contados da sua ciência. Este deverá ser dirigido para autoridade hierarquicamente superior àquela que proferiu a decisão, que deverá se manifestar no prazo de 5 (cinco) dias.

No caso de decisão denegatória exarada por órgãos ou entidades do Poder Executivo Federal caberá recurso à Controladoria Geral da União que deliberará no prazo de 5 (cinco) dias. É importante atentar para o fato de que a LAI conferiu à CGU atribuições de um órgão especializado na apreciação de recursos proferidos por tais instituições. Trata-se de uma espécie de recurso hierárquico impróprio, uma vez que é direcionado a uma autoridade que não é hierarquicamente superior à recorrida, ainda que integrantes da mesma pessoa política (a União). Ocorre, no entanto, que a Lei limita tal recurso para determinadas hipóteses ${ }^{49}$.

Em primeiro lugar, deve haver o esgotamento das vias recursais da autoridade que proferiu a decisão, ou ao menos que o recurso seja submetido a, no mínimo, uma autoridade hierarquicamente superior a que emanou a decisão. Outrossim, é necessário que o recurso se enquadre em um dos permissivos legais: (i) negação de acesso à informação não classificada como sigilosa; (ii) negativa de acesso à informação total ou parcialmente sigilosa ausente a indicação da autoridade classificadora ou hierarquicamente superior a quem possa ser dirigido o pedido de acesso ou desclassificação; (iii) quando os procedimentos de classificação de informação sigilosa não tiverem sido

\footnotetext{
${ }^{49}$ ARAÚJO, Flaviane Ribeiro de. O procedimento recursal na Lei de Acesso à Informação. Revista Brasileira de Direito Público - RBDP, Belo Horizonte, ano 10, n. 37, abr./jun. 2012. Disponível em:<http://www.bidforum.com.br/bid/PDI0006.aspx?pdiCntd=79746>. Acesso em: 27 de outubro de 2012.
} 
observados; (iv) quando houver descumprimento de prazos ou procedimentos da lei.

É de se atentar, no entanto, para o fato de que no caso de a decisão impugnada não indicar a autoridade hierarquicamente superior para a qual deverá ser encaminhado o recurso, não é viável que se exija a submissão prévia a outra autoridade antes de interposição de recurso perante a CGU. Isto porque, é justamente a ausência de tal indicação que obstará a articulação da via recursal e ensejará a hipótese de recurso para a $\mathrm{CGU}^{50}$.

Em caso de provimento do recurso, a CGU determinará que o órgão ou entidade adote as providências necessárias para dar cumprimento ao disposto na Lei. Por outro lado, se for negado o acesso pela CGU poderá ser interposto novo recurso à Comissão Mista de Reavaliação de Informações.

A Comissão Mista de Reavaliação de Informações é instituída pela LAI no art. 35. Ela quem decide no âmbito da Administração Pública Federal sobre o tratamento e classificação de informações sigilosas. Além de ser competente para apreciar os recursos contra decisões denegatórias de acesso proferidas pela CGU, também julga os recursos contra decisões de indeferimento de pedido de desclassificação de informação secreta e ultrassecreta exarados por Ministros de Estado, conforme se verá adiante.

Ademais, soma-se às suas competências (i) a revisão de classificação de informações ultrassecretas ou secretas, mediante provocação de pessoa interessada ou de ofício - neste caso, quando se tratar de documentos secretos ou ultrassecretos a revisão poderá ser feita no prazo máximo de 4 (quatro) anos; (ii) possibilidade de requisição da autoridade que classificar informação como ultrassecreta e secreta esclarecimento ou conteúdo, parcial ou integral da informação; (III) prorrogação - limitada a uma renovação - do prazo de sigilo de informação classificada como ultrassecreta, por prazo determinado, enquanto o seu acesso ou divulgação puder ocasionar ameaça externa à 
soberania nacional ou à integridade do território nacional ou grave risco às relações internacionais do País.

A previsão de instância recursal da CGU e da Comissão é relevante na medida em que traduz uma preocupação da Lei em garantir não apenas a aplicação do direito substancial, mas também a obediência às formalidades previstas, como garantia de legalidade. Em relação ao procedimento recursal a Lei determina a aplicação subsidiária da Lei n. 9.784/1999.

No que se refere aos Poderes Legislativo e Judiciário e ao Ministério Público, o diploma determina que a revisão das decisões denegatórias e a revisão de classificação de documentos sigilosos deverão ser abordadas em regulamentação próprias em seus âmbitos. Não obstante, estabelece que os órgãos do Poder Judiciário e do Ministério Público informarão ao Conselho Nacional de Justiça e ao Conselho Nacional do Ministério Público, respectivamente, as decisões que, em grau de recurso, negarem acesso a informações de interesse público.

\subsubsection{Exceções ao Direito}

A LAI consagra de forma ampla o direito de acesso à informação, mas prevê nos arts. 22 a 30 suas exceções. Antes de tratar das exceções, ressalta no art.21 a garantia ao acesso quando se tratar de informação necessária à tutela judicial ou administrativa de direitos fundamentais, sendo vedada sua negação. Acrescenta ainda, que as informações que versem sobre condutas que impliquem violação dos direitos humanos praticada por agentes públicos ou a mando de autoridades públicas não poderão sofrer restrições. Portanto, a Lei reconhece expressamente que a regulamentação infraconstitucional não poderá restringir direitos fundamentais, o que seria manifestamente inconstitucional.

\footnotetext{
${ }^{50}$ Ibid.
} 
O diploma legal ressalva expressamente que as previsões nele contidas devem respeitar as demais hipóteses legais de sigilo e de segredo de justiça e as hipóteses de segredo industrial decorrentes da exploração direta de atividade econômica pelo Estado ou por pessoa física ou entidade privada que tenha qualquer vínculo com o poder público.

No que tange às exceções o art.23 estabelece:

"Art. 23. São consideradas imprescindíveis à segurança da sociedade ou do Estado $e$, portanto, passíveis de classificação as informações cuja divulgação ou acesso irrestrito possam:

I - pôr em risco a defesa e a soberania nacionais ou a integridade do território nacional;

II - prejudicar ou pôr em risco a condução de negociações ou as relações internacionais do País, ou as que tenham sido fornecidas em caráter sigiloso por outros Estados e organismos internacionais;

III - pôr em risco a vida, a segurança ou a saúde da população;

IV - oferecer elevado risco à estabilidade financeira, econômica ou monetária do País;

$V$ - prejudicar ou causar risco a planos ou operações estratégicos das Forças Armadas;

VI - prejudicar ou causar risco a projetos de pesquisa e desenvolvimento científico ou tecnológico, assim como a sistemas, bens, instalações ou áreas de interesse estratégico nacional;

VII - pôr em risco a segurança de instituições ou de altas autoridades nacionais ou estrangeiras e seus familiares; ou

VIII - comprometer atividades de inteligência, bem como de investigação ou fiscalização em andamento, relacionadas com a prevenção ou repressão de infrações.".

Neste bojo, o art. $4^{\circ}$, III, define informação sigilosa como "aquela submetida temporariamente à restrição de acesso público em razão de sua imprescindibilidade para a segurança da sociedade e do Estado.". Desta forma, enquadrando-se a informação em uma das hipóteses previstas no art. 23, seu acesso será restrito, sempre por tempo determinado, variando o prazo de acordo com seu grau e classificação. É possível que, ao invés de prazo, seja estabelecido como termo final da restrição de acesso a ocorrência de um determinado evento, desde que este se dê antes do transcurso do prazo máximo 
de classificação. Transcorrido o prazo ou consumado o evento, a informação será automaticamente acessível ao público.

A Lei determina que observado o seu "teor e em razão de sua imprescindibilidade à segurança da sociedade ou do Estado" a informação seja classificada em uma das três modalidades de sigilo previstas, podendo ser reservada, secreta e ultrassecreta com prazos de 5 (cinco), 15 (quinze) e 25 (vinte e cinco) anos respectivamente.

Neste aspecto, é importante ressaltar que a LAI diminui os prazos de sigilo previstos anteriormente - que eram de 5 (cinco) anos para reservadas, 20 (vinte) para secretas e 30 (trinta) para ultrassecretas - e suprime a categoria "confidencial", tais previsões constavam no Decreto n. 2.134/1997 regulamentador do art. 23 da Lei n. 8.159/1991 que tratava do acesso e do sigilo dos arquivos públicos e foi revogada pela nova Lei (o Decreto $n$. $4.553 / 2002$ repetiu tais prazos em seu artigo $7^{\circ}$ ).

Para a classificação deverá ser observado o interesse público da informação e utilizado o critério menos restritivo possível, considerando-se (i) a gravidade do risco ou dano à segurança da sociedade e do Estado; (ii) o prazo máximo de restrição de acesso ou evento que defina seu termo final.

O diploma já antecipa que no caso de existência de informações que possam colocar em risco a segurança do Presidente e Vice Presidente da República e seus cônjuges e filhos deverá ser aplicada a classificação "reservada" e o sigilo sobre tais informações deverá ser mantido até o término do mandato em exercícios - ou do ultimo mandato no caso de reeleição.

Uma vez enquadrada a informação dentre uma das modalidades de sigilo, seu acesso e divulgação deverão ser controlados e protegidos pelas autoridades que as mantêm, sendo limitados às pessoas que tenham necessidade de conhecê-la e àquelas devidamente credenciadas, sem prejuízo das atribuições dos agentes públicos autorizados por lei. Aquele que obtiver acesso à informação será obrigado a resguardar o sigilo. 
No que tange a hipótese de documento que contenha informações classificadas em diferentes graus de sigilo, o art. 33 do Decreto regulamentador n. 7.724/2012 determina que será atribuído ao documento tratamento do grau de sigilo mais elevado, ficando assegurado o acesso às partes não classificadas por meio de certidão, extrato ou cópia, com ocultação da parte sob sigilo.

A competência para a classificação do sigilo varia de acordo com o grau de sigilo imposto. $\mathrm{O}$ art. $3^{\circ}$ dispõe acerca de tal classificação, in verbis:

"Art. 30. A classificação de informação é de competência:

I - no grau ultrassecreto, das seguintes autoridades:

a) Presidente da República;

b) Vice-Presidente da República;

c) Ministros de Estado e autoridades com as mesmas prerrogativas;

d) Comandantes da Marinha, do Exército, da Aeronáutica; e

e) Chefes de Missões Diplomáticas e Consulares permanentes no exterior;

II - no grau secreto, das autoridades referidas no inciso I do caput, dos titulares de autarquias, fundações, empresas públicas e sociedades de economia mista; $e$ III - no grau reservado, das autoridades referidas nos incisos I e II do caput e das que exerçam funções de direção, comando ou chefia do Grupo-Direção e Assessoramento Superiores - DAS, nível DAS 101.5 ou superior, e seus equivalentes.

$\mathrm{O}$ art. $27, \S 1^{\circ}$, prevê a possibilidade de delegação das classificações ultrassecreta e secreta pela autoridade responsável a agente público - inclusive em missão no exterior - vedada a subdelegação. A classificação de informação como ultrassecreta quando feita por Comandantes da Marinha, do Exército e da Aeronáutica e Chefes de Missões Diplomáticas e Consulares permanente no exterior que envie para os Ministros de Estado para ratificação. Neste e nos demais casos em que a informação for classificada como ultrassecreta por qualquer autoridade ou agente público é necessário o encaminhamento da ato que decidiu a classificação à Comissão Mista de Reavaliação de Informações.

A decisão que classifica a informação em qualquer um dos casos de sigilo deverá ser formal e conterá necessariamente: (i) o assunto que versa a informação; (ii) o fundamento da classificação; (iii) a indicação do prazo ou evento que limitará o tempo de sigilo; (iv) a identificação da autoridade que a 
classificou). A referida decisão também será mantida sob sigilo pelo mesmo grau da informação protegida.

A Lei prevê a possibilidade de desclassificação ou redução do prazo de sigilo, mediante provocação ou de ofício pela própria autoridade classificadora ou autoridade hierarquicamente superior. Caso ocorra a redução, o novo prazo terá como termo inicial a data de sua produção. A autoridade máxima de cada órgão ou entidade, publicará anualmente, em sítio na internet e destinado à veiculação de dados e informações administrativas: (i) o rol de informações desclassificadas nos últimos 12 (doze) meses; (ii) o rol de documentos classificados em cada grau de sigilo; (iii) relatório estatístico contendo a quantidade de pedidos de informação recebidos, atendidos e indeferidos, bem como informações genéricas sobre os solicitantes.

\subsubsection{Tratamento de Informações Pessoais}

$\mathrm{O}$ art. $4^{\circ}$ define informação pessoal como "aquela relacionada à pessoa natural identificada ou identificável". Seu tratamento é disciplinado no art. 31, que determina a atenção à forma transparente e respeito à intimidade, vida privada, honra e imagem das pessoas, bem como às liberdades e garantias individuais.

As informações pessoais, independentemente da classificação de sigilo, terão restrição ao seu acesso pelo prazo máximo de 100 (cem) anos a contar da sua data de produção, limitado a agentes públicos legalmente autorizados e à pessoa a que elas se referirem. É possível ainda sua divulgação a terceiros, no caso de haver previsão legal ou consentimento expresso da pessoa a que elas se referirem. Por oportuno, responderá pelo uso indevido aquele que obtiver acesso às informações.

Este consentimento é ressalvado, sendo permitido o acesso independente dele, no caso de (i) à prevenção e diagnóstico médico, quando a 
pessoa estiver física ou legalmente incapaz, e para utilização única e exclusivamente para o tratamento médico; (ii) à realização de estatísticas e pesquisas científicas de evidente interesse público ou geral, previstos em lei, sendo vedada a identificação da pessoa a que as informações se referirem; (iii) ao cumprimento de ordem judicial; (iv) à defesa de direitos humanos; ou (v) à proteção do interesse público e geral preponderante.

Por óbvio, a restrição de acesso não poderá ser invocada com o intuito de prejudicar processo de apuração de irregularidades em que o titular das informações estiver envolvido, bem como em ações voltadas para a recuperação de fatos históricos de maior relevância.

\subsubsection{Responsabilidades}

Os artigos 32 a 34 prevêem as penalidades pelo descumprimento dos preceitos da lei, são elas:

"Art. 32. Constituem condutas ilícitas que ensejam responsabilidade do agente público ou militar:

I - recusar-se a fornecer informação requerida nos termos desta Lei, retardar deliberadamente o seu fornecimento ou fornecê-la intencionalmente de forma incorreta, incompleta ou imprecisa;

II - utilizar indevidamente, bem como subtrair, destruir, inutilizar, desfigurar, alterar ou ocultar, total ou parcialmente, informação que se encontre sob sua guarda ou a que tenha acesso ou conhecimento em razão do exercício das atribuições de cargo, emprego ou função pública;

III - agir com dolo ou má-fé na análise das solicitações de acesso à informação;

IV - divulgar ou permitir a divulgação ou acessar ou permitir acesso indevido à informação sigilosa ou informação pessoal;

$V$ - impor sigilo à informação para obter proveito pessoal ou de terceiro, ou para fins de ocultação de ato ilegal cometido por si ou por outrem;

VI - ocultar da revisão de autoridade superior competente informação sigilosa para beneficiar a si ou a outrem, ou em prejuízo de terceiros;

VII - destruir ou subtrair, por qualquer meio, documentos concernentes a possíveis violações de direitos humanos por parte de agentes do Estado." 
Cabe ressaltar que as penalidades variam de acordo com o agente. No caso das Forças Armadas constituem transgressões militares médias ou graves, desde que não tipificadas como crime ou contravenção penal. Em relação aos servidores públicos, são consideradas infrações administrativas apenadas no mínimo com suspensão, seguidos os critérios da Lei n. 8.112/1990. Para ambos, agentes públicos e militares, sem prejuízo das penalidades dos regulamentos, poderão responder também por improbidade administrativa.

No caso de se tratar de pessoa física ou jurídica detentora de informações em virtude de vínculo com o Poder Público, as sanções previstas são: (i) advertência; (ii) multa; (iii) rescisão do vínculo com o poder público; (iv) suspensão temporária de participar de licitação e impedimento de contratar com a administração pública por prazo não superior a 2 (dois) anos; e (v) declaração de inidoneidade para licitar ou contratar com a administração pública, até que seja promovida a reabilitação perante a própria autoridade que aplicou a penalidade - nestes casos, somente será possível após o prazo de 2 (dois) anos e deverá ser efetivado o ressarcimento ao órgão ou entidade dos prejuízos resultantes, ressalta-se ainda que a aplicação desta penalidade é de competência exclusiva da autoridade máxima do órgão ou entidade pública. A penalidade de multa poderá ser acumulada às penalidades de advertência, rescisão do vínculo e suspensão temporária, conforme o caso.

É importante destacar que os órgãos e entidades públicas, bem como a pessoa física ou entidade privada com vínculo com o Poder Público, responderão diretamente pelos danos causados em decorrência da divulgação não autorizada ou utilização indevida de informações sigilosas ou pessoas, cabendo a apuração de responsabilidade funcional nos casos de dolo ou culpa, assegurado o direito de regresso. 


\subsubsection{Alterações na Lei n. $8.112 / 1990$}

Com intuito de promover a transparência e combater a corrupção, a LAI trouxe uma importante inovação para o regime dos servidores públicos federais. Neste sentido, alterou-se a redação do inciso VI do art. 116, da Lei n. 8.112, que passou a ter a seguinte dicção:

"Art. 116. São deveres do servidor:

VI - levar as irregularidades de que tiver ciência em razão do cargo ao conhecimento da autoridade superior ou, quando houver suspeita de envolvimento desta, ao conhecimento de outra autoridade competente para apuração;"

Com efeito, a nova redação permite que quando a suspeita recair sobre autoridade superior a um determinado agente público a ela subordinada, essa questão seja levada ao conhecimento de outra autoridade com intuito de garantir a melhor controlabilidade dos atos que se perpassam dentro dos próprios quadros da Administração Pública.

Para garantir a efetividade da nova redação, a Lei n. 12.527/2011 acrescentou o seguinte artigo à Lei de servidores públicos federais:

"Art. 126-A. Nenhum servidor poderá ser responsabilizado civil, penal ou administrativamente por dar ciência à autoridade superior ou, quando houver suspeita de envolvimento desta, a outra autoridade competente para apuração de informação concernente à prática de crimes ou improbidade de que tenha conhecimento, ainda que em decorrência do exercício de cargo, emprego ou função pública."

Dessa forma, garante-se a proteção do servidor que, no estrito cumprimento de seus deveres, descobre irregularidade e a reporta para autoridade competente. Andou bem o legislador neste tocante, uma vez que garantiu a efetividade da norma, vedando a possibilidade de represálias ao servidor público. 
Aliás, conforme demonstrado essa é a preocupação em geral da lei, disponibilizar mecanismos/garantias que permitam a efetiva concretização do direito.

\subsection{Recentes Repercussões da Lei}

Em que pese se tratar de diploma legal ainda bastante recente, já se podem observar as primeiras e importantes manifestações jurisdicionais no sentido da aplicação da Lei de Acesso à Informação como meio de resguardar a publicidade.

Com efeito, o STF, em recentíssimas decisões, vem utilizando a Lei como forma de garantir ampla publicidade e acesso às informações imbuídas de caráter público. As discussões que adquiriram maior relevo versam sobre a divulgação nominal dos salários dos agentes públicos.

Em decisão proferida nos autos do Pedido de Suspensão de Liminar $n^{\circ}$ 630, ajuizado pelo Município de Porto Alegre, o Supremo Tribunal Federal autorizou a divulgação dos vencimentos dos servidores do referido Município. O então presidente do STF, Ministro Ayres Britto, em decisão monocrática, suspendeu os efeitos da liminar concedida pelo juízo da $4^{\mathrm{a}}$ Vara da Fazenda Pública de Porto Alegre, nos autos de ação ordinária ajuizada pelo Sindicato dos Municipários de Porto Alegre (Simpa), que impedira a divulgação nominal dos vencimentos dos servidores municipais. Os efeitos da liminar foram suspensos até que haja o trânsito em julgado da ação ordinária ajuizada pelo Simpa.

Na referida decisão, o Ministro Relator afirmou que a remuneração dos servidores constitui informação de interesse coletivo ou geral, consoante o disposto no art. 5o, XXXIII, da CRFB/1988. De outro lado, o Sindicato sustentou que a divulgação nominal afrontaria o princípio constitucional da inviolabilidade da privacidade. O Município, por sua vez afirmou que a 
decisão reclamada teria gerado "grande instabilidade nas Administrações Públicas e fomentado a insurgência de servidores quanto às deliberações dos gestores públicos quanto ao tema da transparência”. A decisão do Município de divulgar os salários nominais teria seguido parâmetros utilizados pelos Tribunais Superiores, pelo Governo Federal, pelo Conselho Nacional de Justiça, entre outros.

A competência do STF para apreciar o pedido de suspensão de segurança - medida excepcional para salvaguardar a ordem, a saúde, a segurança e a economia públicas contra perigo de lesão - é decorrência da matéria constitucional em discussão, qual seja, o direito fundamental de acesso a informação (art. $5^{\circ}$, XXXIII, art. 216, § $2^{\circ}$ e art. $373^{\circ}$, II, todos da CRFB/1988) e o princípio da publicidade na atuação administrativa (art. 37, caput, da CRFB/1988). Seguem abaixo trechos relevantes da decisão:

“(...)5. Ora, no caso dos autos, é evidente estar-se diante de matéria constitucional, devido a que as decisões impugnadas versam o tema do direito fundamental de acesso à informação pública (inciso XXXIII do art. $5^{\circ}$, inciso II do $\S 3^{\circ}$ do art. 37 e $\$ 2^{\circ}$ do art. 216, todos da Constituição Federal), de parelha com o princípio igualmente constitucional da publicidade da atuação administrativa (caput do art. 37 da CF). Princípio que, para além da simples publicidade do agir de toda a Administração Pública, propicia o controle da atividade estatal até mesmo pelos cidadãos. Donde a facilitada conclusão de que decisões judiciais contrárias a tais normas constitucionais de proa gera grave lesão à ordem pública.

6. Como ainda se faz de facilitada percepção, a remuneração dos agentes públicos constitui informação de interesse coletivo ou geral, nos exatos termos da primeira parte do inciso XXXIII do art. $5^{\circ}$ da Constituição Federal. Sobre o assunto, inclusive, o Plenário deste Supremo Tribunal Federal já se manifestou. (...)

8. Por fim, registro que, quando da entrada em vigor da recente Lei $n^{o}$ 12.527/2011 (Lei de Acesso à Informação Pública), esta nossa Corte decidiu "divulgar, de forma ativa e irrestrita, os subsídios dos ministros e a remuneração dos servidores do quadro de pessoal do Supremo Tribunal Federal, assim como os proventos dos ministros aposentados, dos servidores inativos e dos pensionistas". O que se deu 
na quarta sessão administrativa, realizada em 22 de maio de 2012, por unanimidade.

9. Ante o exposto, defiro o pedido para suspender os efeitos da liminar concedida nos autos da Ação Ordinária $n^{o}$ 001-1.12.0152707-5, até o trânsito em julgado do processo.(...)"

(STF, SL 630 RS , Rel.: Min. Presidente Ayres Britto, j.: 30/07/2012, DJE: 08/08/2012, grifou-se $)^{51}$

A decisão é de grande relevância, pois demonstra as primeiras repercussões da Lei, e pode indicar o modo através do qual sua aplicação será realizada pela referida Corte. Em primeiro lugar, salienta-se que é louvável a proteção ampla conferida ao acesso e divulgação das informações de interesse público. O passo tomado pela Corte Suprema é importante para a formação de uma cultura de transparência e controle.

Justamente pelo seu pioneirismo, faz-se pertinente uma análise mais criteriosa da(s) referida(s) decisão(es) - os parênteses têm cabimento, pois a Corte fundamentou outros dois precedentes, de questões fáticas e jurídicas semelhantes, no mesmo sentido - uma vez que suas linhas de fundamentação poderão ser responsáveis pelos rumos em que se encaminharão as próximas decisões.

A questão repousa na seguinte antítese: ao mesmo tempo em que se assegurou constitucionalmente o princípio da publicidade e o acesso às informações guardadas pelos órgãos públicos, sujeitou-se seu conteúdo às restrições legais previstas no art. $5^{\circ}, \mathrm{LX}$, vedando-se sua divulgação quando se atente contra a intimidade ou o interesse social.

Está em tela uma colisão entre dois princípios: o princípio da publicidade e o princípio da intimidade. É cediço que, ao contrário das regras, que são binárias e aplicadas, normalmente, segundo a lógica do "tudo ou

\footnotetext{
${ }^{51}$ No mesmo sentido, confiram-se as seguintes decisões monocráticas: STF, SL 623 DF, Rel.: Min. Presidente Ayres Britto , j.: 10/07/2012, Data de Publicação: DJE: 03/08/2012 e STF, SS 4661 DF , Relator: Min. Presidente Ayres Britto, j.:21/08/2012, DJE: 27/08/2012.
} 
nada", os princípios possuem uma dimensão de peso, podendo ser aplicados em maior ou menor grau, dependendo do caso concreto e dos princípios em colisão. A medida do grau de aplicação de cada princípio deve ser avaliada de acordo com um juízo de ponderação. A ponderação consiste em uma técnica de decisão em que se avalia, diante do caso concreto, qual o princípio será preponderante. Neste sentido, Luís Roberto Barroso, afirma:

"Relembre-se, como já assentado, que os princípios, por sua estrutura e natureza, e observados determinados limites, podem ser aplicados com maior ou menor intensidade, à vista de circunstâncias jurídica ou fáticas, sem que isso afete sua validade. Pois bem: nessa fase dedicada à decisão os diferentes grupos de normas e a repercussão dos fatos do caso concreto estarão sendo examinados de forma conjunta, de modo a apurar os pesos que devem ser atribuídos aos diversos elementos em disputa e, portanto, o grupo de normas que deve preponderar no caso. Em seguida, será preciso ainda decidir quão intensamente esse grupo de normas - e a solução por ele indicada - deve prevalecer em detrimento aos demais, isto é: sendo possível graduar a intensidade da solução escolhida, cabe ainda decidir qual deve ser o grau apropriado em que a solução deve ser aplicada. Todo esse processo intelectual tem como fio condutor o princípio da proporcionalidade ou razoabilidade. ${ }^{, 52}$

No caso em questão (divulgação das remunerações dos agentes públicos), parece claro que o princípio que prevalece é o da publicidade. A remuneração dos servidores públicos constitui informação de interesse coletivo ou geral. Isto porque a destinação e gerência do dinheiro público devem ser de conhecimento da população em atendimento ao princípio constitucional da publicidade e efetivação da transparência das contas públicas, também como forma de promover a eficiência administrativa no atendimento aos cidadãos e viabilizar o controle e fiscalização pelos cidadãos e órgãos de controle da atuação administração.

52 BARROSO, Luís Roberto. Curso de direito constitucional contemporâneo: os conceitos 
Ocorre, entretanto, que uma ressalva deve ser feita. Não obstante a clara preponderância do princípio da publicidade no caso em questão, deve-se analisar até que ponto há a necessidade de ser afastada a aplicação do princípio da intimidade. Nesse sentido é valioso recorrer mais uma vez aos ensinamentos de Luis Roberto Barroso:

"A ponderação, como estabelecido acima, socorre-se do princípio da razoabilidade-proporcionalidade para promover a máxima concordância prática entre os direitos em conflito. Idealmente, o intérprete deverá fazer concessões recíprocas entre valores e interesses em disputa, preservado o máximo possível de cada um deles. Situações haverá, no entanto, em que será impossível a compatibilização. Nesses casos, o intérprete precisará fazer escolhas, determinando, in concreto, o princípio ou direito que irá prevalecer". ${ }^{53}$

Conforme leciona o consagrado constitucionalista, apenas em situações em que não seja possível a compatibilização dos princípios é que um deles será "suprimido". Nas demais hipóteses deve-se aplicar a ponderação de forma que seja dada máxima eficácia para cada um.

Nesta toada, cabe a seguinte indagação: no caso analisado, foi dada a máxima eficácia para ambos os princípios? Diante do crivo de um juízo de proporcionalidade, é possível questionar se a divulgação nominal é mesmo a única solução adequada e necessária para o caso concreto. A indignação do sindicato (ora utilizada como base para a presente discussão) recai sobre o fato de a publicidade em questão incorrer na devassidão da esfera privada do servidor, o que poderia acarretar a fragilização da segurança pessoal e patrimonial dos agentes, uma vez que são expostos seu nome, local de trabalho e remuneração.

fundamentais e a construção do novo modelo. $1^{\text {a }}$ Ed.. São Paulo: Saraiva, 2009. p. 335.

${ }^{53}$ Ibid. p. 338 
É certo que os dados em questão dizem respeito a agentes públicos, quando nesta qualidade, razão pela qual incidem sobre eles certas exigências e limitações especiais, tendo em vista que atuam em nome do Estado e recebem seus recursos. Desta maneira, em decorrência do próprio princípio republicano de gestão pública e divulgação dos atos estatais, é dever do Estado prestar tais informações.

No entanto, um vetor da administração deve ser sopesado com outros princípios, principalmente quando estão em jogo garantias fundamentais. No caso em questão, seria possível fazer a divulgação não por lista nominal, mas pelo número de matrícula de cada servidor, hipótese em que o interesse público estaria atendido de igual modo, sem haver interferência desnecessária à intimidade do servidor. Vislumbra-se essa hipótese com a listagem geral das matrículas divulgada de forma espontânea e caso houvesse interesse de verificação de alguma remuneração específica, a correspondência entre o servidor e a matrícula, também seria disponível, porém condicionada a um requerimento.

A decisão do Supremo Tribunal Federal é relevante como marco inicial da aplicação da lei e quebra da cultura do sigilo, pois consagra o direito ao acesso às informações de forma ampla. Entretanto, justamente por ter essa função "desbravadora", deve ser analisada de forma pormenorizada.

Com efeito, a decisão inspira ao menos uma considerável preocupação. É que, embora no caso concreto a aplicação do princípio da publicidade tenha prevalecido amplamente, a Corte Suprema não parece ter tomado o devido cuidado de compatibilizar satisfatoriamente os princípios colidentes, deixando de perseguir a desejável máxima eficácia possível de ambos. Esta falta de harmonização em detrimento do princípio da intimidade pode fazer com que, futuramente, os papéis se invertam e ocorra uma limitação demasiada do princípio da publicidade. É dizer: trata-se de uma faca de dois gumes, pois, da mesma forma que a publicidade foi integralmente prestigiada desta vez, será 
perfeitamente possível que, em casos futuros, venha a ser integralmente rechaçada, criando-se uma lógica de "tudo ou nada" antes de se fazer maiores esforços de compatibilização. De fato, a Lei prevê uma série de formas em que a publicidade dos atos poderia ser atendida sem prejuízo de se conferir uma mínima margem de efetividade a outros princípios porventura colidentes. Exemplo de instrumentos para esta harmonização prática, no caso concreto, são os conceitos de transparência ativa e passiva trazidos.

Em contraposição a essa discussão, traz-se à baila outra recente aplicação da Lei n. 12.527/2011. O juiz eleitoral do TRE da 58ª Zona Eleitoral, Dr. Márlon Jacinto Reis, editou em 9 de maio de 2012 o Provimento $\mathrm{n}^{\circ}$ $01 / 2012$, que determinou que os candidatos fornecessem o nome dos doadores das campanhas antes da realização das eleições.

A edição do provimento se deu antes mesmo da publicação da L. 12.527/2011, mas a referida Lei serviu como embasamento do ato:

“(...)Considerando que todos os âmbitos do Poder Judiciário estão submetidos à Lei de Acesso à Informação (Lei $n^{\circ}$ 12.527, de 18 de novembro de 2011), a qual assegura a "divulgação de informações de interesse público, independentemente de solicitações" (art. $3^{\circ}$, II) e a "gestão transparente da informação, propiciando amplo acesso a ela e sua divulgação" (art. 6", I).

(...)

Os candidatos aos cargos de Prefeito, Vice-Prefeito e Vereador desta $58^{a}$ Zona Eleitoral, que abrange os Municípios de João Lisboa, Buritirana e Senador La Rocque, deverão, nos dias 6 de agosto e 6 de setembro, fornecer em meio digital (em formato de planilha eletrônica) os nomes dos doadores, seus respectivos CNPJ ou CPF, bem como os valores doados por cada um. ${ }^{, 54}$

Após tal iniciativa, juízes de outros estados passaram a exigir a medida de transparência em suas Zonas. A repercussão foi tamanha que a presidente do Tribunal Superior Eleitoral (TSE), Ministra Cármen Lúcia, em

\footnotetext{
${ }^{54}$ Provimento $\mathrm{n}^{\mathrm{o}}$ 01/2012 da $58^{\mathrm{a}}$ Zona Eleitoral do Maranhão, editado pelo juiz eleitoral Márlon
} 
cumprimento à Lei de Acesso à Informação, determinou, por meio da Resolução ${ }^{\circ}$ 23.376, em seu art. 60 que os dados referentes às doações de campanha eleitoral e apresentados por partidos e candidatos fossem disponibilizados no site do TSE na primeira prestação de contas, antes da eleição.

Ao contrário da lei eleitoral (Lei n. 9.504/1997), que determinava em seu artigo 28, §4 $4^{\circ}$, a indicação dos nomes dos doadores dos valores das campanhas somente na prestação de contas final, após as eleições, a Resolução permitiu que o eleitor tivesse acesso a quem estava financiando cada candidato antes de votar. A Resolução foi extremamente positiva na medida em que colabora para os mecanismos de intensificação de transparência e combate à corrupção

Tamanha foi sua importância do ponto de vista da democracia, que possibilitou tanto um incremento na fiscalização das contas e conscientização do eleitor, quanto na consolidação da lei em questão, utilizada de forma ponderada e coerente para os fins que foi proposta. 


\section{CONCLUSÃO}

O princípio da publicidade viabiliza o acesso à informação e propicia o controle da atuação estatal. $\mathrm{O}$ acesso às informações é decorrência do sistema democrático e do modelo republicano, tratando-se de instrumento indispensável à fiscalização e responsabilização do governo.

A acessibilidade, contudo, está condicionada não apenas à divulgação das informações, mas também à efetiva apreensão de seu conteúdo. Nesse sentido, traz-se à luz o conceito de transparência, que objetiva a transmissão do teor da informação de forma clara e sem excessivos formalismos, permitindo sua correta compreensão por aquele que a recebe.

Com efeito, a Lei de Acesso à Informação trouxe novos e importantes mecanismos que facilitam a divulgação da informação - e sua proteção quando necessária -, garantindo a efetividade do direito. A forma de atuação da Administração, o modo de elaboração dos requerimentos, a determinação da divulgação espontânea de determinadas matérias, a tramitação dos pedidos de informação, a estipulação de prazos, recursos e penalidades para o descumprimento, tudo isso diminui a discricionariedade do administrador e facilita o acesso do cidadão.

Tão ou mais importante que isto, a Lei é responsável por iniciar uma cultura de transparência, já discutida e implementada em diversos países, mas ainda tímida no plano nacional. As recentes repercussões da LAI demonstram o começo deste processo que possibilitará maior conhecimento das atuações públicas.

Não obstante as inovações trazidas, é necessário atentar para o fato de que ainda existem uma série de obstáculos de diferentes ordens a serem ultrapassados para que o princípio vigore.

Em primeiro lugar, pode-se citar obstáculos relativos à própria Lei, no que tange à sua implementação e obediência. A Lei n. 12.527/2011 fica 
condicionada a regulamentos estaduais e no âmbito do Legislativo e do Judiciário para garantir a atuação dos órgãos consoante suas diretrizes. Enquanto tais regulamentos não forem editados, a eficácia da lei será obviamente restringida.

Ademais, somente com a prática será possível verificar se as formalidades da Lei serão respeitadas. Para a efetivação do direito é necessária a observância dos prazos e formas previstos. Neste contexto, as responsabilidades impostas à Corregedoria Geral da União e à Comissão Mista de Reavaliação de Informações são valiosas, pois permitem que haja uma fiscalização externa, além daquela feita pelo próprio requerente.

Segundo, aponta-se a barreira em relação ao próprio servidor. Muitos agentes públicos ainda não estão preparados para caminhar no sentido da acessibilidade, seja porque ainda não assumiram uma postura a favor do acesso, ou ainda devido a empecilhos de ordem prática.

A CGU, em parceria com a UNESCO, sob a coordenação do professor Roberto DaMatta, realizou no ano passado uma pesquisa para o Projeto denominado "Política Brasileira de Acesso a Informações Públicas: garantia democrática do direito a informação, transparência e participação cidadã”. A pesquisa teve como objetivo principal a análise de valores, cultura, experiência e percepção de servidores públicos federais em relação à temática de acesso a informação.

A pesquisa, embora tenha constatado um crescente movimento de abertura e conscientização da transparência, elencou uma série de desafios a serem superados para implementação da Lei de Acesso à Informação, dentre eles o enfrentamento da cultura do sigilo:

"Por outro lado, desafios deverão ser enfrentados para a implementação bem sucedida da Lei. O primeiro deles é o enfrentamento da cultura do segredo, identificada principalmente na constante preocupação com o "mau uso" das informações pelo público, 
com a "má interpretação" ou "descontextualização das informações". A busca pelo controle das informações - o que está sendo informado, para quem e com qual objetivo - apareceu como prática recorrente.

Isto porque, muitas vezes, as informações sob a guarda da Administração Pública são tratadas como sendo de propriedade do Estado, dos departamentos e em alguns casos dos próprios servidores, que as arquivam em seus computadores ou pendrives pessoais $e$ as levam para casa. $O$ controle das informações, especialmente dos bancos de dados, cria um status diferenciado e garante o espaço político dos técnicos dentro de seus órgãos. Por isso, há resistência em disponibilizar informações não só para o público, mas às vezes até para outras áreas da Administração. ${ }^{55}$,"

Soma-se a isto as dificuldades no processamento dos pedidos de informação. Muitas vezes o servidor não é devidamente instruído, o que dificulta sua atuação, na medida em que não sabe como proceder para distinguir as informações que são ou não sigilosas. É preciso que lhes seja fornecida uma definição clara do que é ou não informação pública a fim de que se diminua a margem de arbítrio pessoal para as decisões de denegação das solicitações, bem como a disponibilização proativa de dados e informações da Administração, quando estas forem exigidas.

Além dos desafios de ordem cultural, a pesquisa também constatou obstáculos operacionais e técnicos. O processo de produção, registro, classificação, armazenagem e disponibilização da informação varia dentro do âmbito da Administração, coexistindo situações bastante distintas no que tange à gestão da informação. Segundo a pesquisa:

"Enquanto algumas áreas possuem sistemas de informação e bancos de dados modernos, processos digitalizados, sistemas e vários canais de comunicação com a sociedade, outras ainda estão na era do papel,

\footnotetext{
${ }^{55}$ CONTROLADORIA GERAL DA UNIÃO. Sumário Executivo: Pesquisa diagnóstico sobre valores, conhecimento e cultura de acesso à informação pública no Poder Executivo Federal Brasileiro. Disponível em http://www.acessoainformacao.gov.br/acessoainformacaogov/publicacoes/SUMARIO_FINAL.pdf >. Acesso em 27 de outubro de 2012.
} 
enfrentando dificuldades para localizar documentos, sistematizar informações básicas e controlar o fluxo de pedidos e de respostas. Uniformizar esta realidade exigirá recursos financeiros e recursos humanos na área de Tecnologia da Informação."

Outra mudança necessária para efetiva utilização e aplicação da Lei advém do próprio cidadão nacional. A cultura brasileira em geral não possui tradição participativa. Nesse sentido, é importante uma postura mais proativa do indivíduo, que deve desenvolver uma atitude de cobrança e fiscalização da Administração para possibilitar tanto o acesso em si, como a consolidação do princípio democrático.

Neste aspecto, os meios digitais são de grande auxílio. A própria lei prevê diversas facilitações em virtude do meio eletrônico. Embora o Brasil não seja ainda totalmente integrado tecnologicamente, essa pluralização telemática é importante para difundir ainda mais a informação e aumentar o fluxo de trocas.

Em suma, a Lei n. 12.527/2011 apresenta-se como importante instrumento para consolidação da democracia, pois implementa uma série de mecanismos que efetivam o acesso a informação e consagram o respeito ao princípio da publicidade. Ademais, representa uma mudança de paradigma cultural de uma cultura do segredo para uma cultura do acesso. De todo modo, ela sozinha não é capaz de promover todas essas transformações. Faz-se necessária a realização de uma série de outras mudanças, tanto culturais dos servidores e cidadãos, como de ordem prática de implementação de tecnologia e edição de regulamentos. 


\section{BIBLOGRAFIA}

ARAÚJO, Flaviane Ribeiro de. O procedimento recursal na Lei de Acesso à In formação. Revista Brasileira de Direito Público - RBDP, Belo Horizonte, ano 10, n. 37, abr.jjun. 2012. Disponível em: <http://www.bidforum.com.br/bid/PDI0006.aspx?pdiCntd=79746>. Acesso em: 27 de outubro de 2012.

BAPTISTA, Patrícia. Transformações do direito administrativo. Rio de Janeiro: Renovar, 2003. p. $221-260$.

BARROSO, Luís Roberto. Curso de direito constitucional contemporâneo: os conceitos fundamentais e a construção do novo modelo. Ed. 1 ${ }^{\text {a }}$. São Paulo: Saraiva, 2009. P. $335-338$.

BINENBOJM, Gustavo. O princípio da publicidade administrativa e a eficácia da divulgação de atos do poder público pela internet. Salvador: Revista Eletrônica de Direito do Estado, 2009. Disponível em: <https://www2.mp.pa.gov.br/sistemas/gcsubsites/upload/39/princdapublicidad e.pdf $>$. Acesso em: 26 de setembro de 2012.

CARDOSO, André Guskow. $O$ direito de acesso a informações: panorama derivado da Lei $n^{o}$ 12.527, 18 de novembro de 2011. Informativo Justen, Pereira, Oliveira, Talamini, Curitiba, $\mathrm{n}^{\mathrm{o}}$ 63, maio de 2012. Disponível em $\langle$ http://www.justen.com.br//informativo.php?informativo $=63 \& \operatorname{artigo}=653\rangle$. Acesso em 26 de junho de 2012.

CONTROLADORIA GERAL DA UNIÃO. Sumário Executivo: Pesquisa diagnóstico sobre valores, conhecimento e cultura de acesso à informação pública no Poder Executivo Federal Brasileiro. Disponível em < http://www.acessoainformacao.gov.br/acessoainformacaogov/publicacoes/SU MARIO_FINAL.pdf >. Acesso em 27 de outubro de 2012.

FERREIRA, Aurélio Buarque de Holanda. Mini Aurélio Século XXI: o minidicionário da língua portuguesa. $4^{\mathrm{a}}$ Ed. Rio de Janeiro: Nova Fronteira, 2002. p. $566-567$.

FURTADO, Lucas Rocha. Curso de Direito Administrativo. Belo Horizonte: Fórum, 2007. p.108- 110.

JUSTEN FILHO, Marçal. Curso de direito administrativo. $8^{\mathrm{a}}$ Ed. Belo Horizonte: Fórum, 2012. p.180 -181; 309 -311; 446- 447. 
KEANE, John. Vida e Morte da Democracia. 70 ed. São Paulo: Almedina, 2010 p. $22-28$.

MADEIRA, José Maria Pinheiro. Administração Pública. 10a ed. Rio de janeiro: Elsevier, 2008. p. 25 - 33.

MENDEL, Toby. Liberdade de informação: um estudo de direito comparado. 2 ed. Brasília: UNESCO, 2009. p. 1 -7.

MOREIRA NETO, Diogo de Figueiredo. Mutações do Direito Administrativo. Rio de Janeiro: Renovar, 2000. p. 7 - 36.

MOREIRA, Egon Bockmann. Processo Administrativo: Princípios Constitucionais e a Lei 9.784/1999. $2^{a}$ Ed. São Paulo: Malheiros. 2003. p. 125 -141 .

O'DONNELL,Guillermo. Accountability horizontal e novas poliarquias. São Paulo: Revista Lua Nova, N44, 1998. Disponível em $<$ http://www.scielo.br/scielo.php?pid=S0102-

$\underline{64451998000200003 \& \text { script=sci arttext }>}$. Acesso em 26 de setembro de 2012.

PAES, Eneida Bastos. A Construção da Lei de Acesso à Informação Pública no Brasil: desafios na implementação de seus princípios. Revista do Serviço Público. Brasília out/dez 2011. P.407 - 418

SILVA, José Afonso da. Curso de Direito Constitucional Positivo. $30^{a}$ Ed. São Paulo: Malheiros. p.669-671.

.Entrevista do Ministro-Chefe da Controladoria Geral da União, Jorge Hage, ao programa Bom Dia Ministro transmitido em 30/08/2012. Disponível em <http://www.cgu.gov.br/Ministro/ArtigosEntrevistas/itens/entrevista_2012083 0_JorgeHage_RadioNacional_AM.asp>. Acesso em 27 de outubro de 2012.

.Assessoria de Comunicação Social da CGU. "Hage participa, nos EUA, do lançamento da Parceria para Governo Aberto". Disponível em 〈http://www.cgu.gov.br/Imprensa/Noticias/2011/noticia16611.asp〉. Acesso em 27 de outubro de 2012. 